\title{
Human Impact on the Planet: An Earth System Science Perspective and Ethical Considerations
}

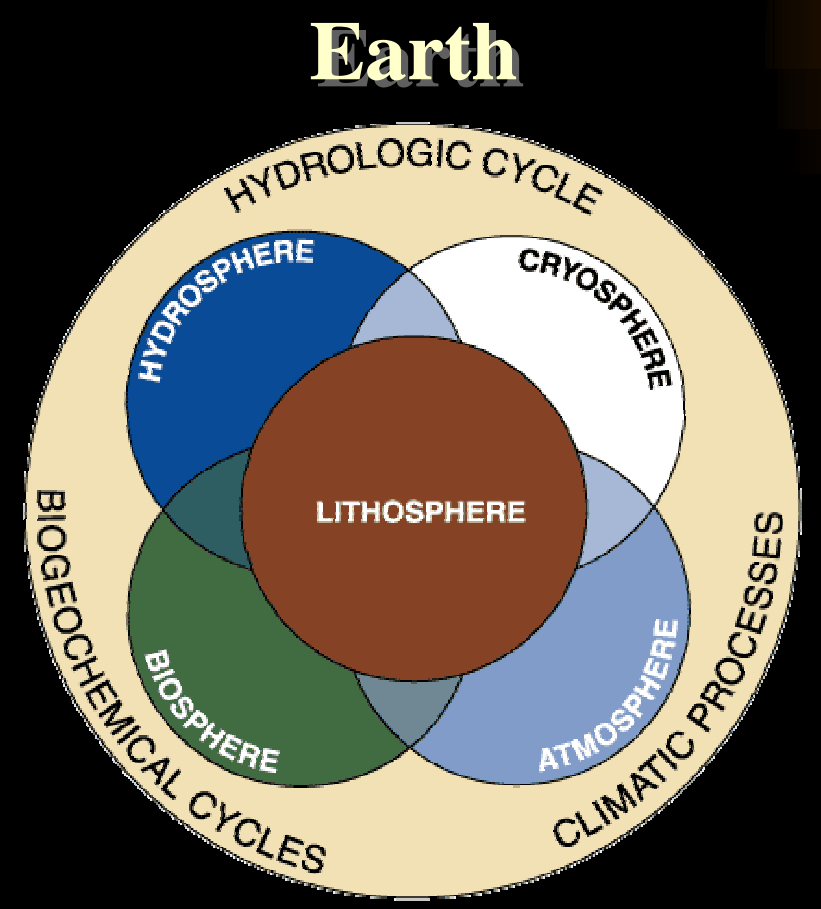

Richard S. Williams, J r., Ph.D.

Research Geologist-ST

U.S. Geological Survey

Woods Hole Field Center

384 Woods Hole Road

Woods Hole, MA 02543-1598 U.S.A. 


\section{Iceland 2000: Faith in the Future}

The Role of Religion and Science in the New Millennium

HUMAN IMPACT ON THE PLANET: AN EARTH SYSTEM SCIENCE PERSPECTIVE AND ETHICAL CONSIDERATIONS ${ }^{1,2,3}$

Richard S. Williams, Jr., Ph.D.

U.S. Geological Survey

Woods Hole Field Center - 384 Woods Hole Road

Woods Hole, MA 02543-1598 U.S.A.

(Tel: 508-457-2347; Fax: 508-457-2310e-mail: rswilliams@usgs.gov)

1. Invited presentation prepared for Iceland 2000: Faith in the Future. The Common Task of Religion and Science in the New Millennium held at Háskólabíó v/Hagatorg, IS-107 Reykjavík, Ísland (Iceland) on 6-8 July 2000.

2. The presentation on the morning of 7 July 2000 was extemporaneous (e.g., no written text other than the abstract), and included a mixture of 35-mm color slides and viewgraphs (overhead transparencies). All graphics used are included here, although with some minor changes; additional 35-mm color slides have been added to make the Earth System Science perspective more complete. An explanatory text slide follows each slide where appropriate.

3. The invited presentation is available in three formats: a set of 4335 -mm color slides, PowerPoint, and on the http://www.kirkjan.is/faithinthefuture/ Web site as a post-symposium addition to the abstract and viewgraphs). 


\section{Iceland 2000: Faith in the Future}

\section{The Role of Religion and Science in the New Millennium}

Abstract: The modern Earth Narrative, the scientific story of the 4.5 billion-year natural and human history of the Earth, has emerged from the solid foundation of two factual concepts: Deep (or Geologic) Time and Biological Evolution. Widespread acceptance of the Earth Narrative is critically important as we begin the third millennium, because it provides a clear understanding of the growing impact of human population growth and associated activities on the Earth System, especially the negative impact on Earth's biosphere. It is important for humans to realize that we are but one of 4,500 species of mammals that exist on Earth and that we are but one species in the estimated 30 to 100 million species that form the complex biosphere. We also need to recognize that all species exist within the physical limits imposed by the geosphere. We are totally dependent on the biosphere for food, oxygen, and other necessities of life. Humans are one of the latest results of biological evolution operating over a long period of Geologic Time. We find ourselves on Earth, after 4.5 billion years of Earth history by chance, not by design. Humans have become so successful at modifying their environment that many of the natural limitations on the expansion of populations of our fellow animals have been overcome by technological and cultural innovations. According to Peter Raven, "Humans, at a current population of 6 billion [expected to nearly double by 2050], are consuming or wasting about 50 percent of the total net biological productivity on land and 50 percent of the available supply of freshwater. (Abstract continued on next slide.) 


\section{Iceland 2000: Faith in the Future}

The Role of Religion and Science in the New Millennium

The overwhelming and expanding human presence leaves less and less room in the environment for other biota." The $21^{\text {st }}$ century will be a pivotal time in the fate of Earth's biosphere. Whereas human modification of the geosphere will slowly recover over time, human changes to the biosphere are a far more consequential matterextinction of a species is forever! Will humans effectively use our new knowledge of natural and human history to stop further degradation of Earth's ecosystems and extinction of its biota? The fate of the biosphere, including humanity, depends on a reaffirmation by all humans of all cultures and religions of the global importance of a planet-wide conservation of the Earth's biotic heritage. For the world's religions it means elevation of stewardship of the Earth to a moral imperative and a goal of complete preservation of the Earth's biotic inheritance, one which is based on a Do No Harm ethic. 


\section{Theme 4 Caring for the Future of the Planet}

- Life-support systems of the planet

- Spiritual and ethical dimensions of sustainable development

- Responsible use of resources and environment services - legacy for future generations (stewardship)

- Respect for intrinsic value of nature sustainable development policy-making 
Theme 4. Caring for the Future of our [sic, The] Planet. Conference organizers included four subtopics to be addressed. Stewardship was added by me to the third subtopic, stewardship in a broad, planetwide (Earth System) sense, not in the Biblical or ever modern religious (e.g., annual donation to a specific church) person-to-person sense. In my presentation, I also challenged the absurdity of the term "sustainable development," calling it the ultimate oxymoron when used in the context of the Earth System, essentially an interactive, closed system, with finite resources (e.g., Buckminster Fuller's "Spaceship Earth"). I also renamed Theme 4 to be "Caring for the Future of The [not Our] Planet. Our implies "ownership" by humans, only one of as many as 30 million individual life forms (species) on the planet. "Our Planet" is a concept derived from Judaeo/Christian traditions, especially as presented in the Pentatuch (five books of Moses) of the Old Testament of the Bible. Therefore, referring to "Our Planet" carries a strong emotive overprint that is based on religious values, not scientific fact. (Comments on Theme 4 continued on the next slide.) 


\section{Iceland 2000: Faith in the Future}

The Role of Religion and Science in the New Millennium

It is instructive to note that the concept of "land ownership" was used by European settlers in both North America and Australia to ignore the rights of Native Americans and Aborigines, respectively, by referring to the already-settled land as terra nullilus ("belonging to noone"). Native Americans had already populated North (and South) America at least 15,000 years Before Present (B.P., calculated from A.D. 1950); Aborigines had populated Australia and Tasmania, eventually with approximately 700 tribal groups, at least 50,000 years B.P. 
Iceland 2000: Faith in the Future

The Role of Religion and Science in the New Millennium

\section{Stewardship: Common Ground for Science and Religion}

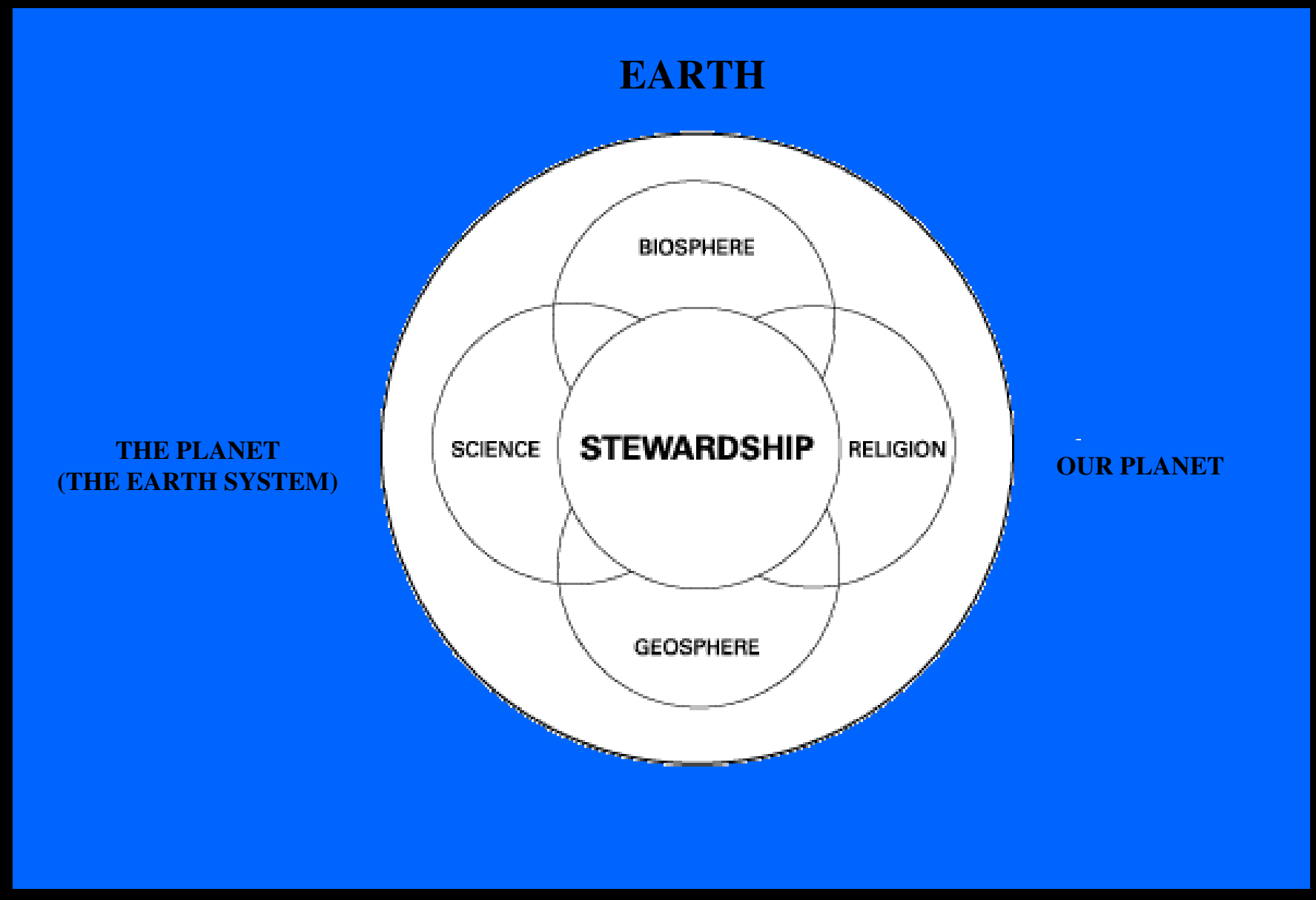




\section{Iceland 2000: Faith in the Future}

The Role of Religion and Science in the New Millennium

This "Venn-type" diagram illustrates the importance of Stewardship when discussing the Earth from the religious ("Our Planet") and Earth System ("The Planet") perspective. Stewardship can provide a "common ground" at the non-overlapping boundary (frontier) between religion and science in consideration of human impact on the geosphere and biosphere, especially the fate of the latter. 
Human Impact on the Planet: An Earth System Science Perspective and Ethical Considerations

- Theme 4-Caring for the Future of the Planet

- Prologue

- The Natural and Human History of the Earth

- The Earth System

- Human Impact on the Earth System

- Scientific and Ethical Challenges to Science and Religion

- Stewardship

- Epilogue 


\section{Prologue}

"To Albert Schweitzer who said "Man has lost the capacity to foresee and to forestall. He will end by destroying the earth.",

- Rachael Carson's dedication in Silent Spring

"We are the most dangerous species of life on the planet, and every other species, even the earth itself, has cause to fear our power to exterminate. But we are also the only species which, when it chooses to do so, will go to great effort to save what it might destroy."

- Wallace Stegner

The earth does not belong to man; man belongs to the earth. This we know... All things are connected. Whatever befalls the earth befalls the sons of the earth. Man did not weave the web of life, he does to himself... This earth is precious to Him [the Creator], and to harm the earth is to heap contempt upon its creator.

- Chief Seattle Suquamish Tribe 19 ${ }^{\text {th }}$ Century 
Prologue. Selected quotations from the works of three well-known environmental writers who addressed the impact of humans on the planet from the perspective of the $19^{\text {th }}$ century (Chief Seattle) and the latter part of the $20^{\text {th }}$ century (Wallace Stegner and Rachael Carson). Rachael Carson is considered by many to be the scientist who first successfully raised the global alarm of human impact on other species. She specifically cited widespread dispersal of synthetic chemicals, in this case the insecticide dichlorodiphenyltrichloroethane (DDT), and its impact on birds, especially thinning of raptor eggshells. 
Iceland 2000: Faith in the Future

The Role of Religion and Science in the New Millennium

\section{The Natural and Human History of the Earth}

- The Earth System

- Geosphere

- Biosphere

- Climatic Processes, Hydrologic Cycle, and Biogeochemical Cycles

- Human Impact on the Earth System 
Iceland 2000: Faith in the Future

The Role of Religion and Science in the New Millennium

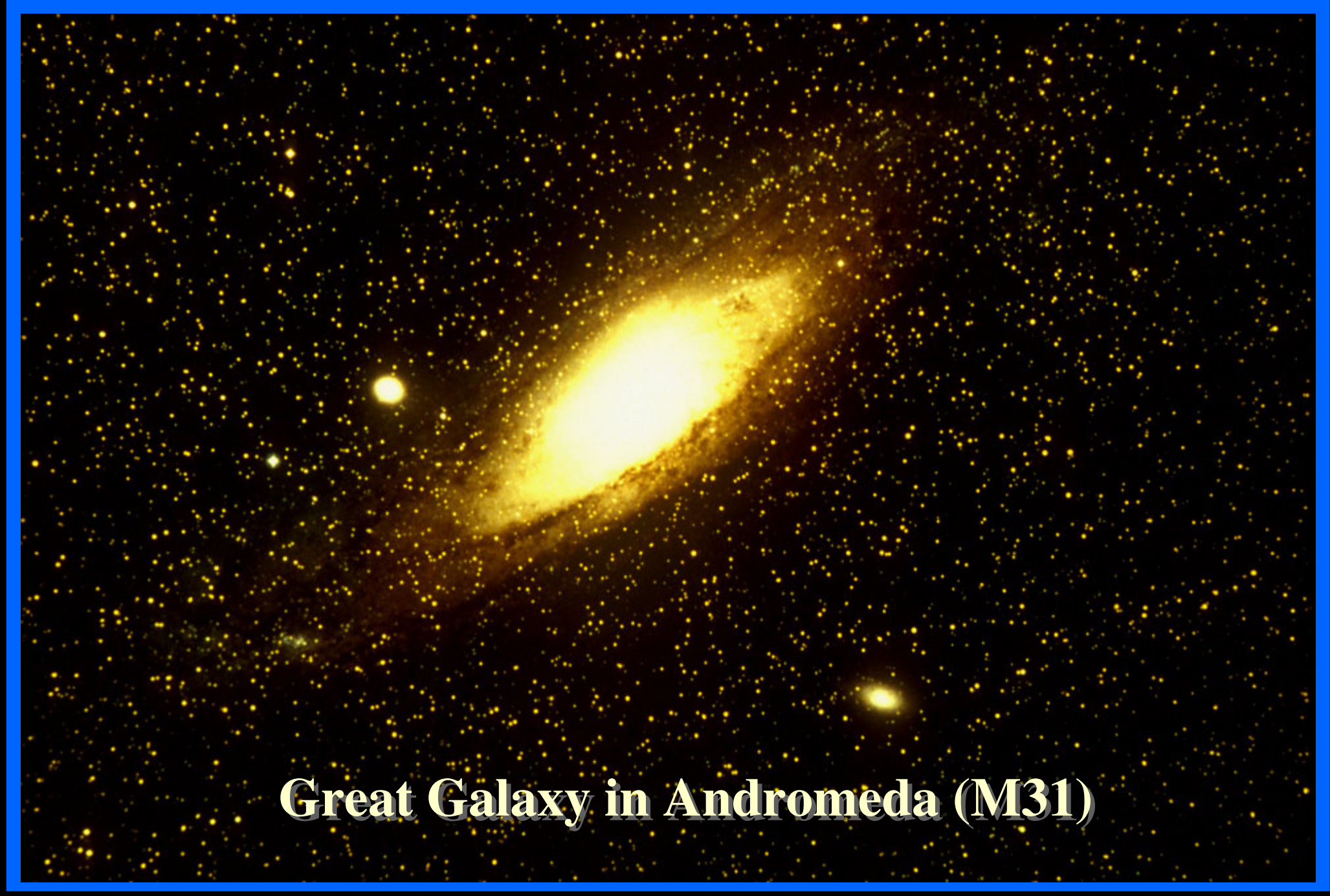




\section{Iceland 2000: Faith in the Future}

The Role of Religion and Science in the New Millennium

Telescopic photograph of the Great Galaxy in Andromeda (NGC 224/Messier 31) taken by the $122 \mathrm{~cm}$ (48 in.) Schmidt telescope at the Hale Observatory (Hale Catalogue No. S-24). The Great Galaxy is 2x106 light years from Earth and is a type of spiral galaxy quite similar to the Milky Way Galaxy in which Earth is situated. The Sun and associated planets, moons, comets, asteroids, etc., is one of an estimated 300 million stars in the Milky Way Galaxy; the Sun is located out on one of the spiral arms. Slide courtesy of the Astronomical Society of the Pacific. 
Iceland 2000: Faith in the Future

The Role of Religion and Science in the New Millennium

\section{The Earth System}


Iceland 2000: Faith in the Future

The Role of Religion and Science in the New Millennium

\section{Apollo 17 Photograph of the Earth}

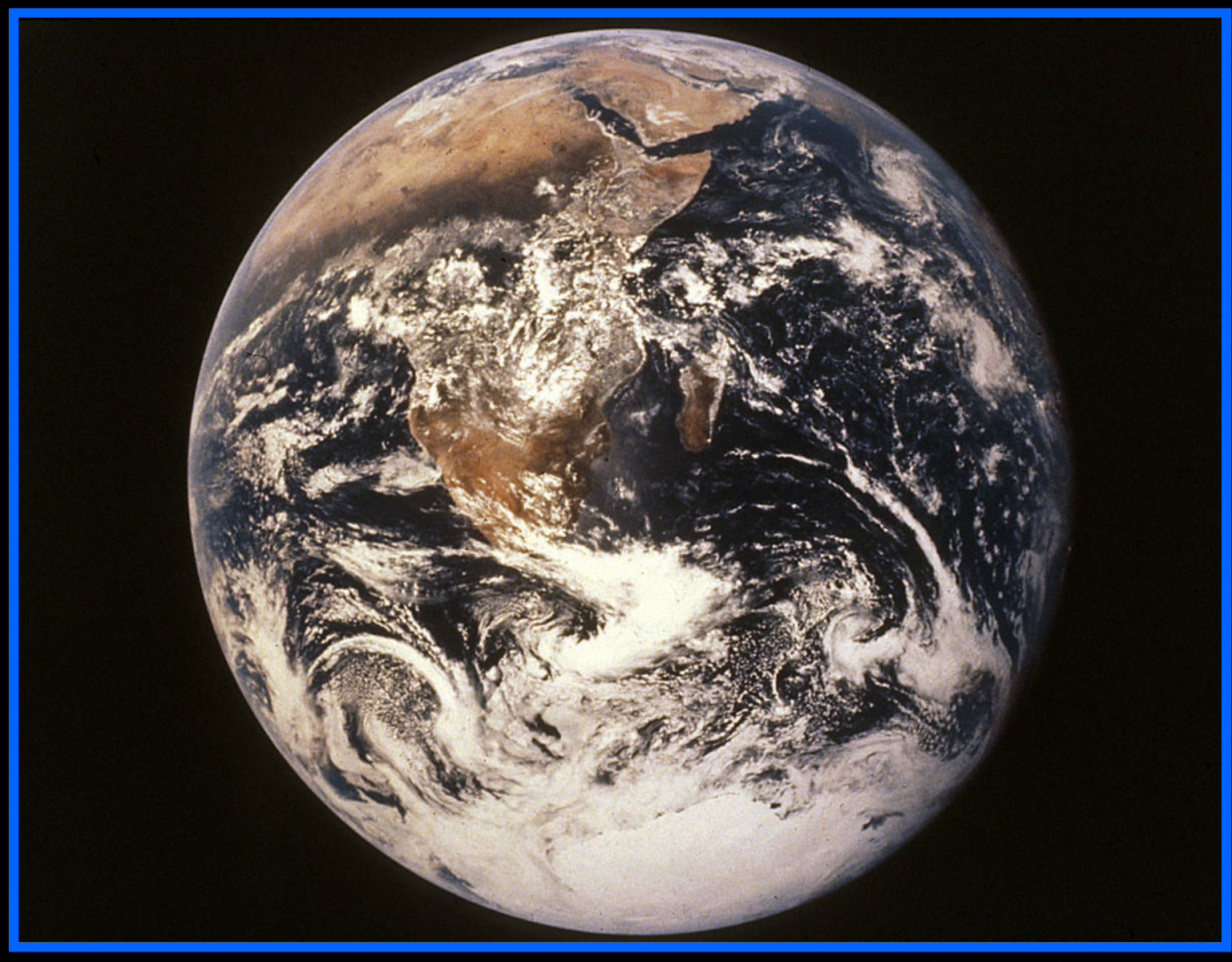


Apollo 17 photograph of the Earth taken in 1972 by the astronaut/geologist Harrison H. Schmidt. Photograph 72-HC-928 courtesy of NASA. Elements of the geosphere [hydrosphere (oceans), lithosphere (Africa and the Middle East), atmosphere (clouds), and cryosphere (glacier-covered Antarctica)] and biosphere (swatch of green rain forest across central Africa), climatic processes (storm systems), and hydrologic cycle (water vapor in the atmosphere, water in the oceans, frozen water in Antarctica, and transpiration from rain forest vegetation) are included in this iconographic photograph of the Earth as a dynamic, interactive, holistic system - from its internal core (not shown) to the upper reaches of the atmosphere. Earth is a misnomer; the planet should really be called Water, because it makes Earth unique in its abundance on the surface and is a critical substance in the support of all known life forms. 
Iceland 2000: Faith in the Future

The Role of Religion and Science in the New Millennium

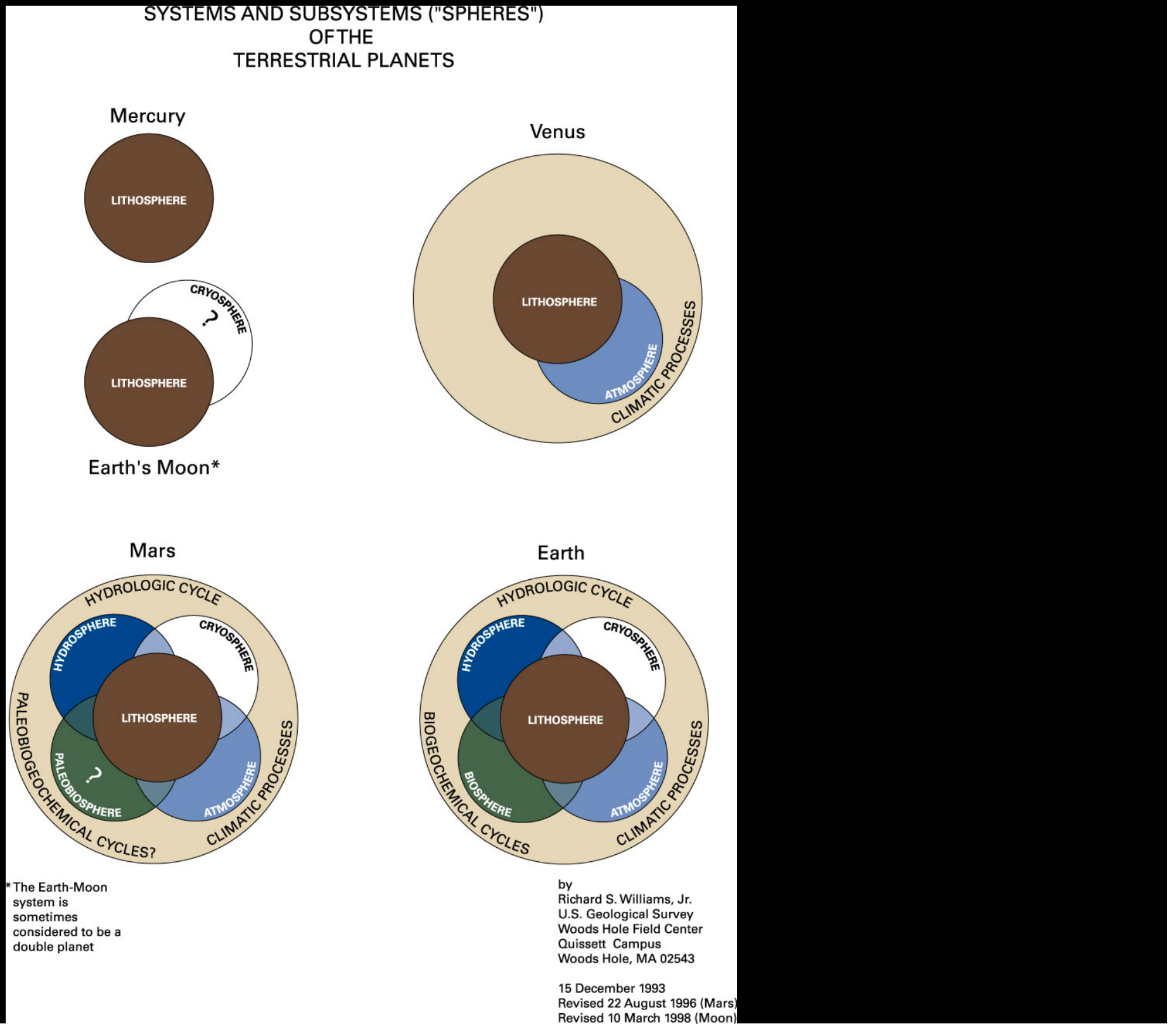


Schematic showing system and subsystems of the terrestrial planets in the Solar System. Note that Mars is the planet most similar to Earth, the reason that NASA is focusing so many exploration missions on this planet during the next decade and beyond. There is a strong possibility that life forms were present earlier in the history of Mars and primitive forms may still be present. Recently, a 250 million-year-old bacterium from a Permian Period (Paleozoic Era) salt formation in New Mexico was found to be viable. 
Iceland 2000: Faith in the Future

The Role of Religion and Science in the New Millennium

\section{Earth}

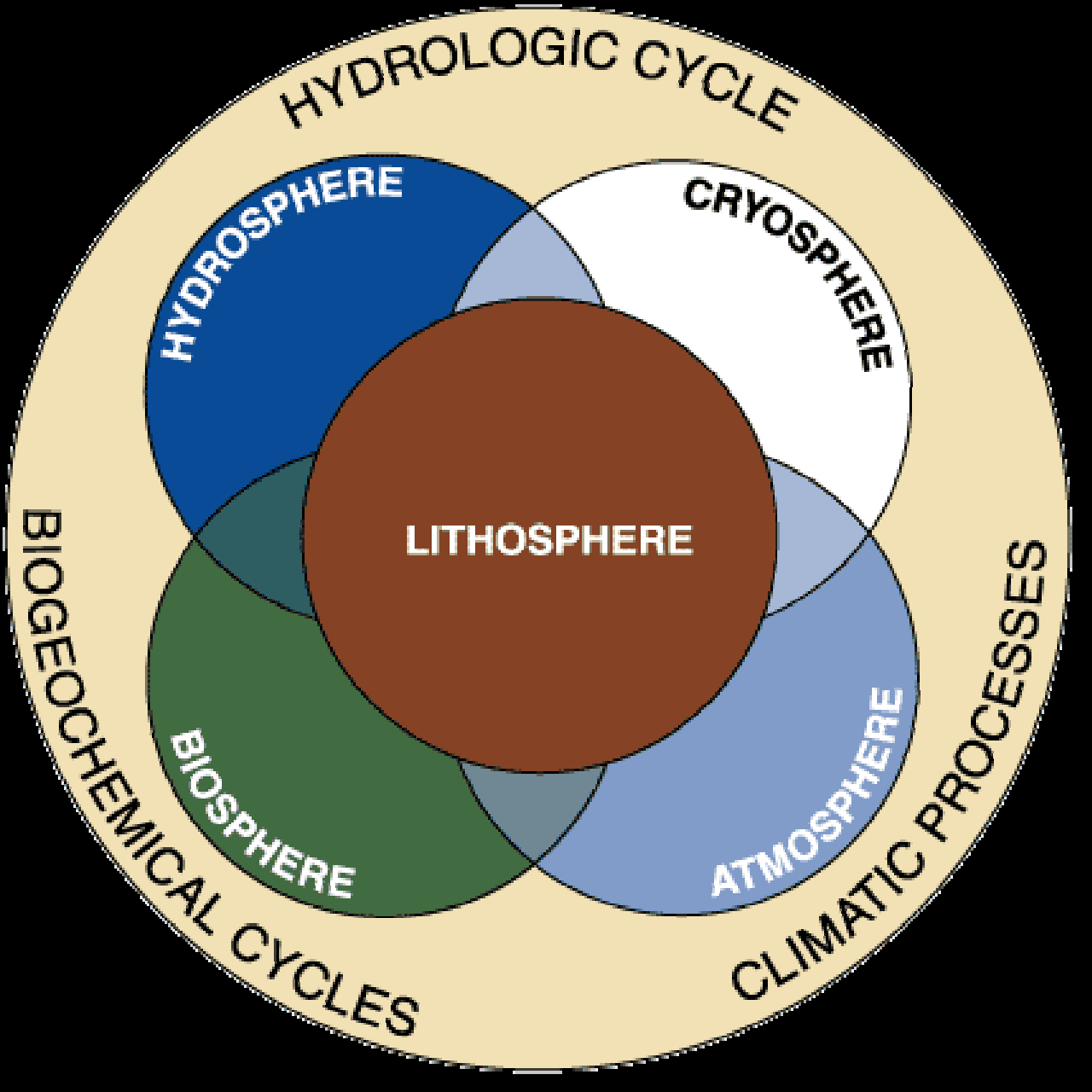




\section{Iceland 2000: Faith in the Future}

The Role of Religion and Science in the New Millennium

The systems and subsystems of Earth are extremely dynamic and interact with each other in complex ways: the geosphere (lithosphere, hydrosphere, atmosphere, and cryosphere) and biosphere, with a vigorous hydrologic cycle, climatic processes, and biogeochemical cycles. Life forms evolved early in Earth's history, at least 3.8 billion years ago $(\mathrm{Ba})$, only a short time after the Earth formed $(4.8 \mathrm{Ba})$ from planetismals that condensed from the solar nebula. 


\section{Iceland 2000: Faith in the Future}

\section{The Role of Religion and Science in the New Millennium}

\section{Evolution of Life on Earth}

\section{Cenozoic era}

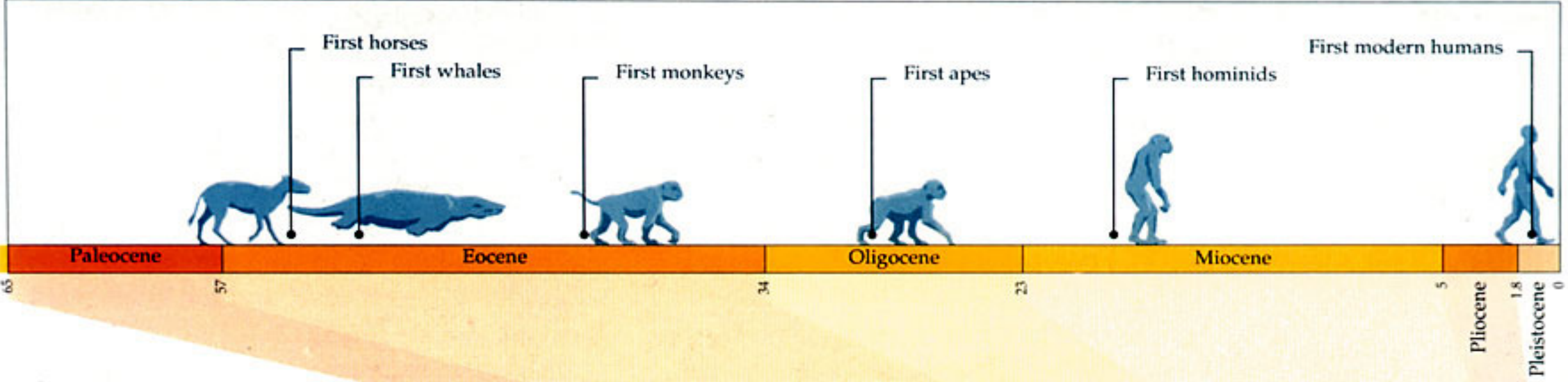

Paleozoic era Mesozoic era

First shellfish \& corals

.

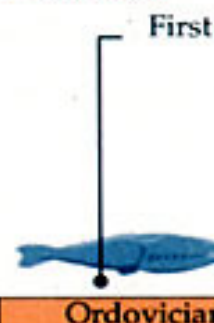

$3 \quad 8$

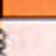

Ordovician

First mammallike reptiles

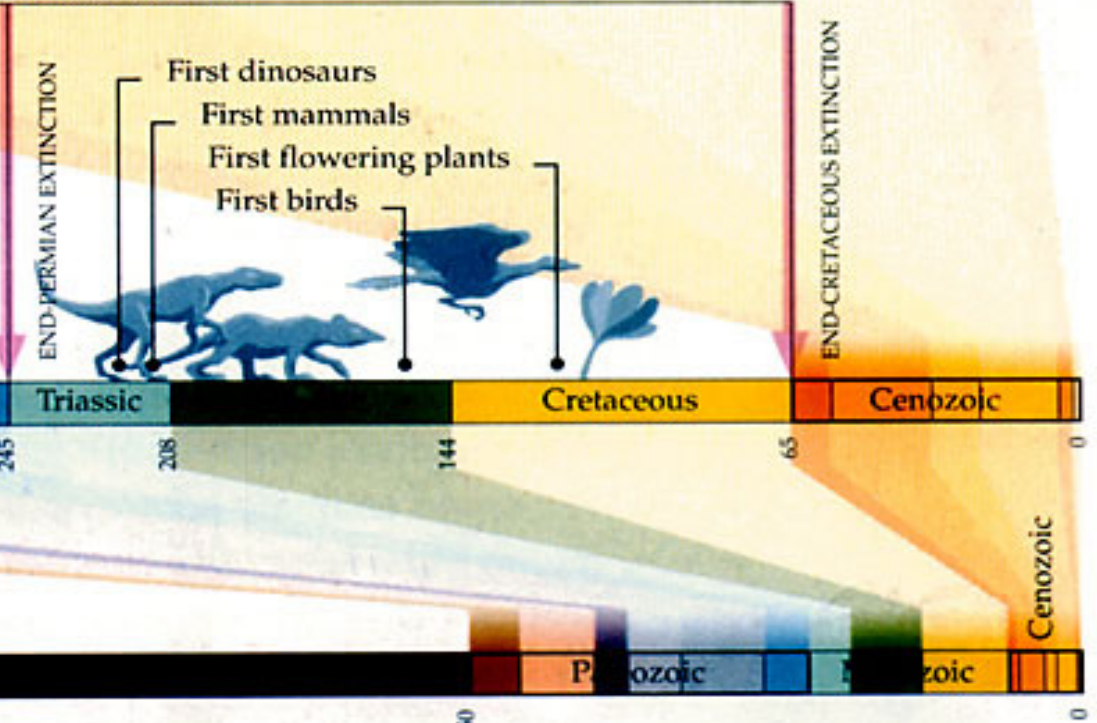


Time line showing the evolution of life (the biosphere) on Earth during the past 4.8 billion years (By). Modern humans only evolved during the past 100 thousand years (100 ky) and represent one of 11 different biped primate mammals (hominids) which evolved during the past 5 million years ( $5 \mathrm{My}$ ), some of which coexisted in time and which are all extinct except our species (Homo sapiens). For example, Neanderthal (Homo sapiens neanderthalensis) coexisted with Homo sapiens until about $30 \mathrm{Ka}$ ago. Diagram from Gould, S.J., gen. ed., 1993, The book of life. An illustrated history of the evolution of life on Earth. New York, W.W. Norton and Co., p. 24-25. 
Iceland 2000: Faith in the Future

The Role of Religion and Science in the New Millennium

Geologic Time Scale (includes extinction events)

Credit: The Miner's Canary, Niles Eldredge, 1991, p. xii and xiii, Prentice Hall Press

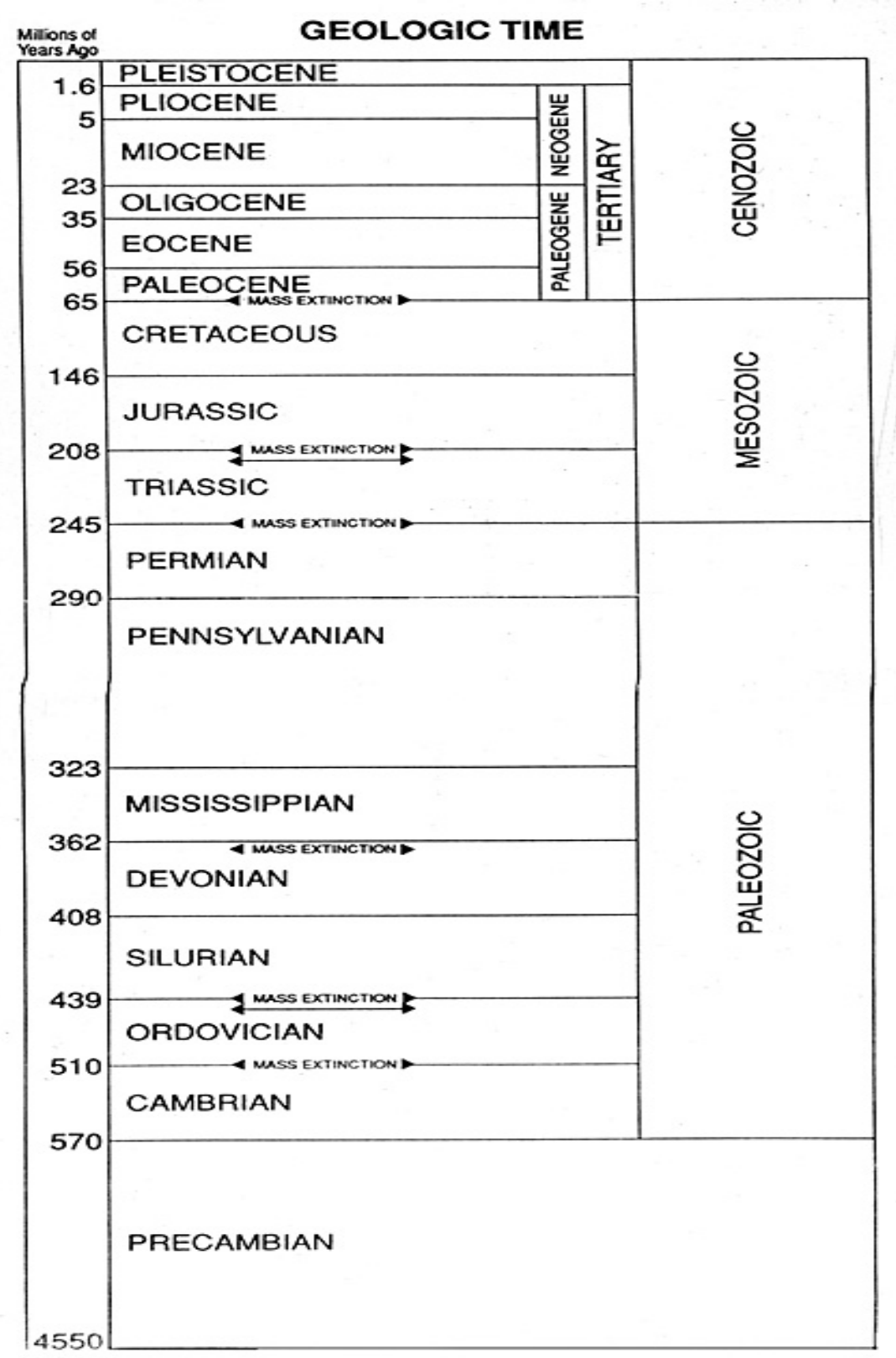


The geologic time scale for the past $570 \mathrm{My}$, showing the eras and periods assigned by geologists to intervals of time during and between in which significant evolution of life forms in the biosphere took place. The boundary between the Cambrian Period and the Precambrian is significant, because multicellular organisms first evolved on Earth in the Lower Cambrian. Life forms evolved into more complex organisms over time, but the evolution in many lineages was not a continuous process during the past $530 \mathrm{My}$, because five major extinction events from extraterrestrial (comets and asteroids) or terrestrial (climate change and megavolcanic eruptions) processes markedly reduced the number of terrestrial and marine species. Evolution continued after each extinction event but from a reduced suite of life forms. Geologic time scale from Eldredge, N., 1991, The miner's canary. Unraveling the mysteries of extinction. New York, Prentice-Hall Press, p. xii-xiii. 
Iceland 2000: Faith in the Future

The Role of Religion and Science in the New Millennium

\section{Collision Course of Earth with a Comet}

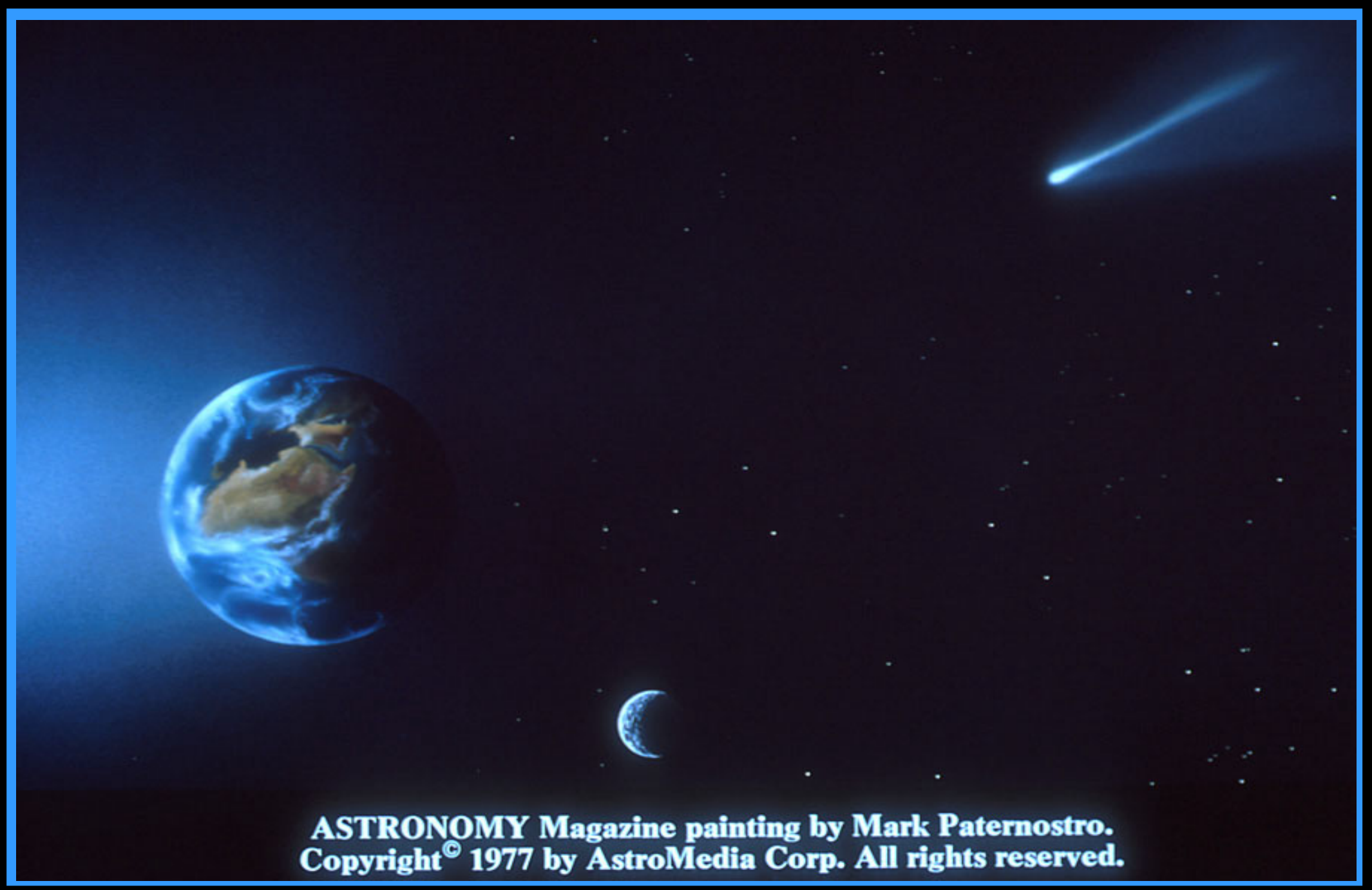


Iceland 2000: Faith in the Future

The Role of Religion and Science in the New Millennium

\section{Crossing the Flat}

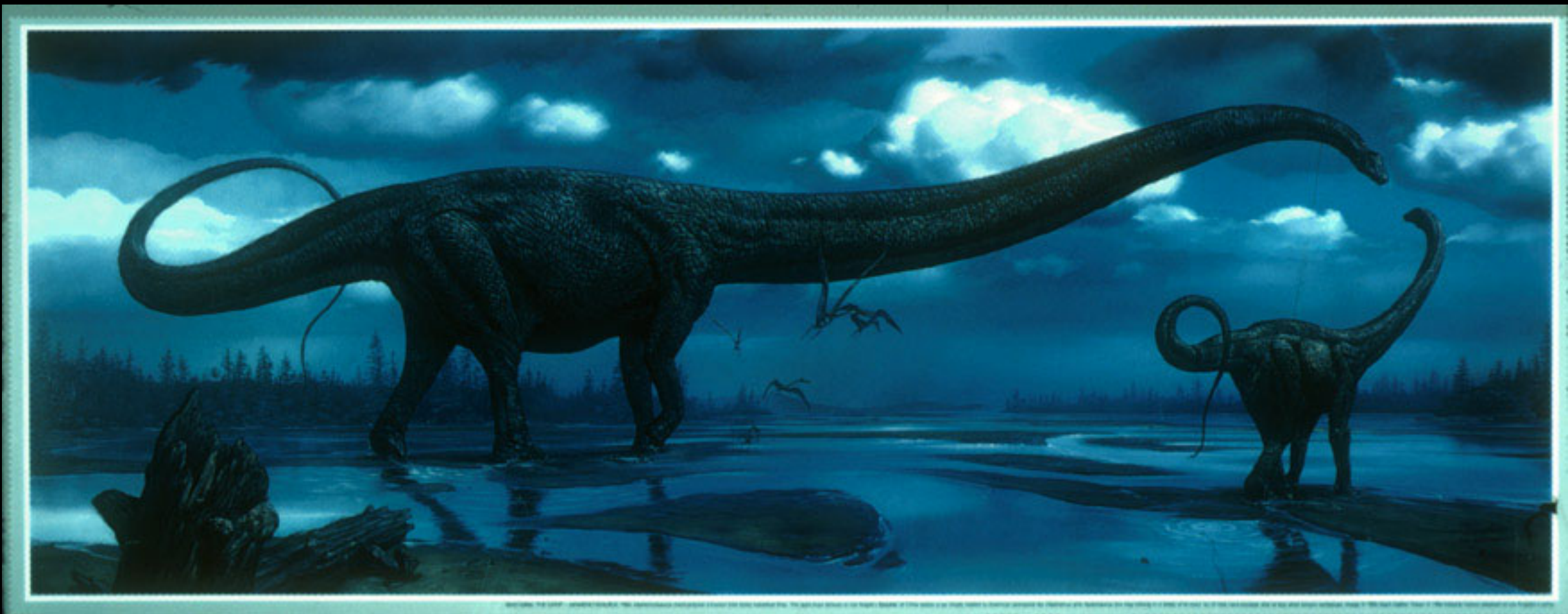

Credit: Dinosaurs Past and Present; Poster @ 1986 Natural History Museum of Los Angeles County; Image @ 1986 Mark Hallet 
Iceland 2000: Faith in the Future

The Role of Religion and Science in the New Millennium

"Crossing the flat." Mesozoic dinosaurs, herbivores and pterodactyls, are portrayed in this poster produced for an exhibition organized by the Natural History Museum of Los Angeles County ${ }^{\odot}$, Dinosaurs Past and Present. The painting, The Giant-Mamonchisaurus hochuanensis-1986 ${ }^{\circ}$. This

Mamonchisauarus, with an $11 \mathrm{~m}$ (33 ft.) neck, is from Sichuan, China; it is related to North American sauropods, Diplodocus and Aptosaurus. Dinosaurs, a dominant group in the biosphere during the Mesozoic, became extinct at the end of the Mesozoic Era (245 Ma-65 Ma), $65 \mathrm{Ma}$ ago, partly due to the consequences of a sudden global climate change caused by an asteroid impact in the Yucatán Peninsula, México/Gulf of Mexico region, marked by the Chicxulub impact crater. 
Iceland 2000: Faith in the Future

The Role of Religion and Science in the New Millennium

Giant Sequoia Tree

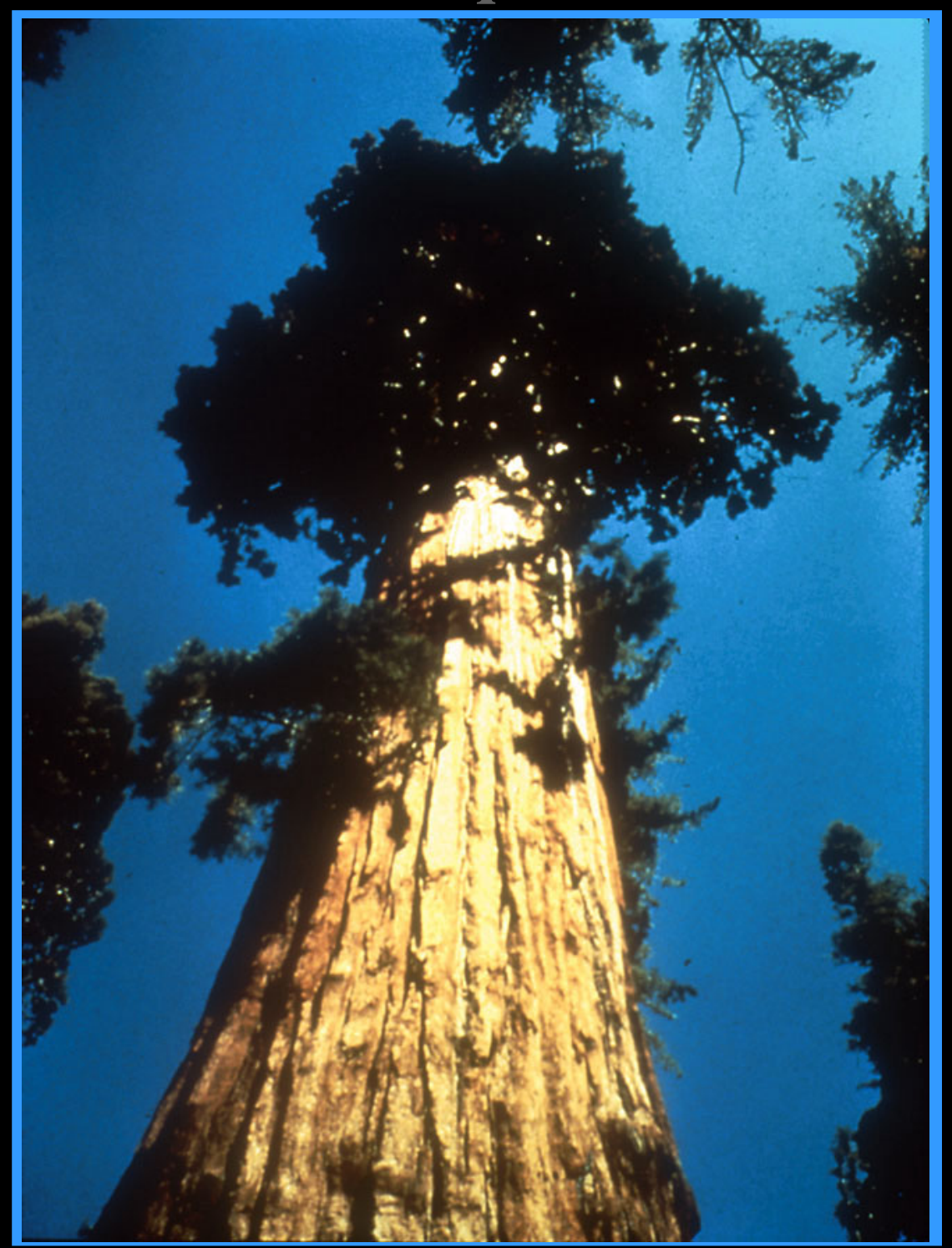




\section{Iceland 2000: Faith in the Future}

The Role of Religion and Science in the New Millennium

Giant Sequoia tree (Sequoya sp.), California, a long-lived conifer, which can exceed $90 \mathrm{~m}$ (300 feet) in height. Source of color photograph unknown; obtained from the U.S. Global Change Research Program. Plants comprise one of the five kingdoms of the biosphere. 
Iceland 2000: Faith in the Future

The Role of Religion and Science in the New Millennium

Oblique Aerial Photograph of Tepuís in Southern Venezuela

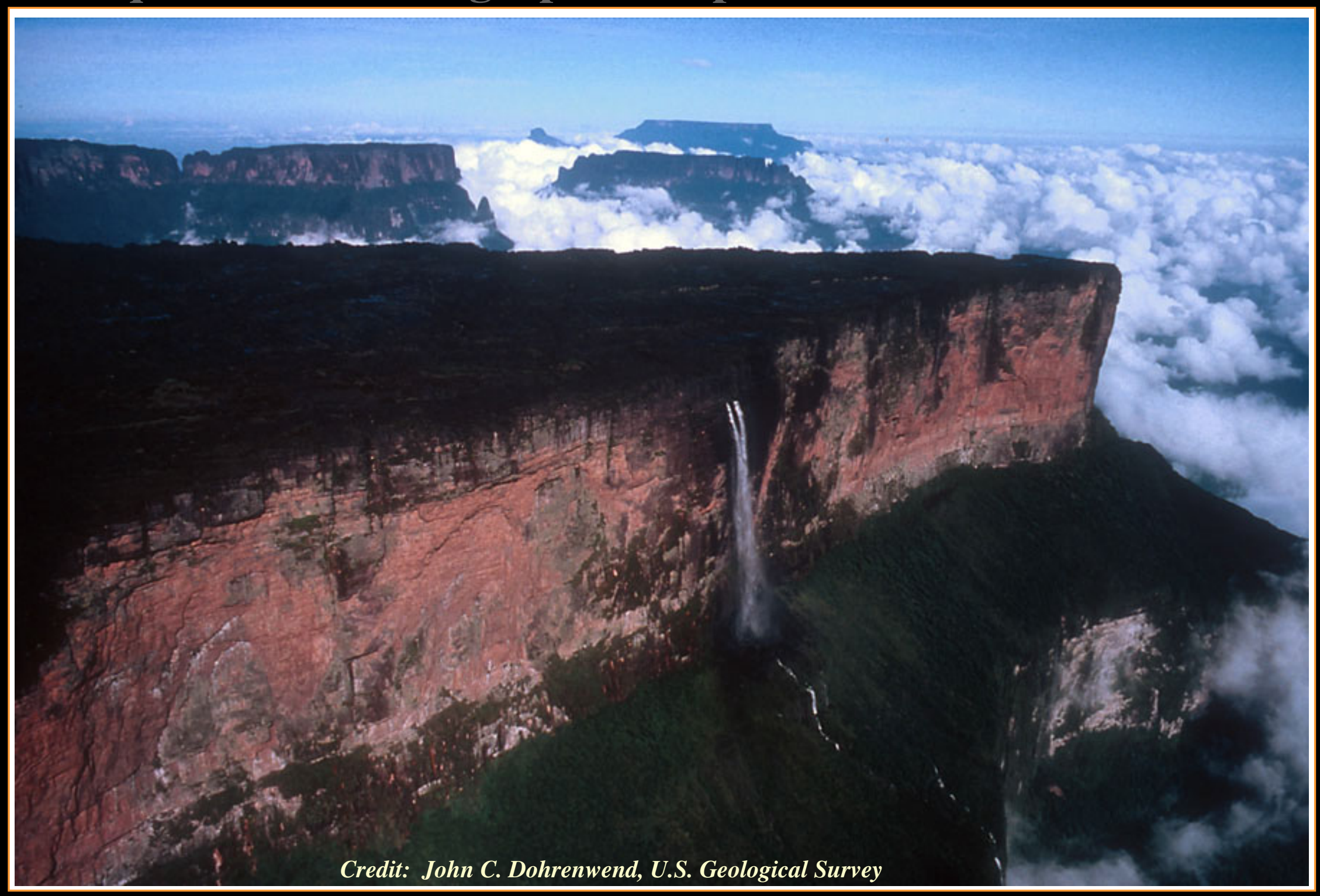


Iceland 2000: Faith in the Future

The Role of Religion and Science in the New Millennium

Oblique color aerial photograph of flat-topped tepuís in La Gran Sabana area of southeastern Venezuela. Tepuís have microclimates and specialized ecosystems (diverse and specialized biota) on their summits where they rise above the surrounding rain forests; the rock formation, an element of the lithosphere, is 1 By-old well-cemented sandstone. Photograph courtesy of John C. Dohrenwend, U.S. Geological Survey. 
Iceland 2000: Faith in the Future

The Role of Religion and Science in the New Millennium

Space Shuttle Photograph of Coral Reets in the Bora-Bora Archipelago, Tahiti

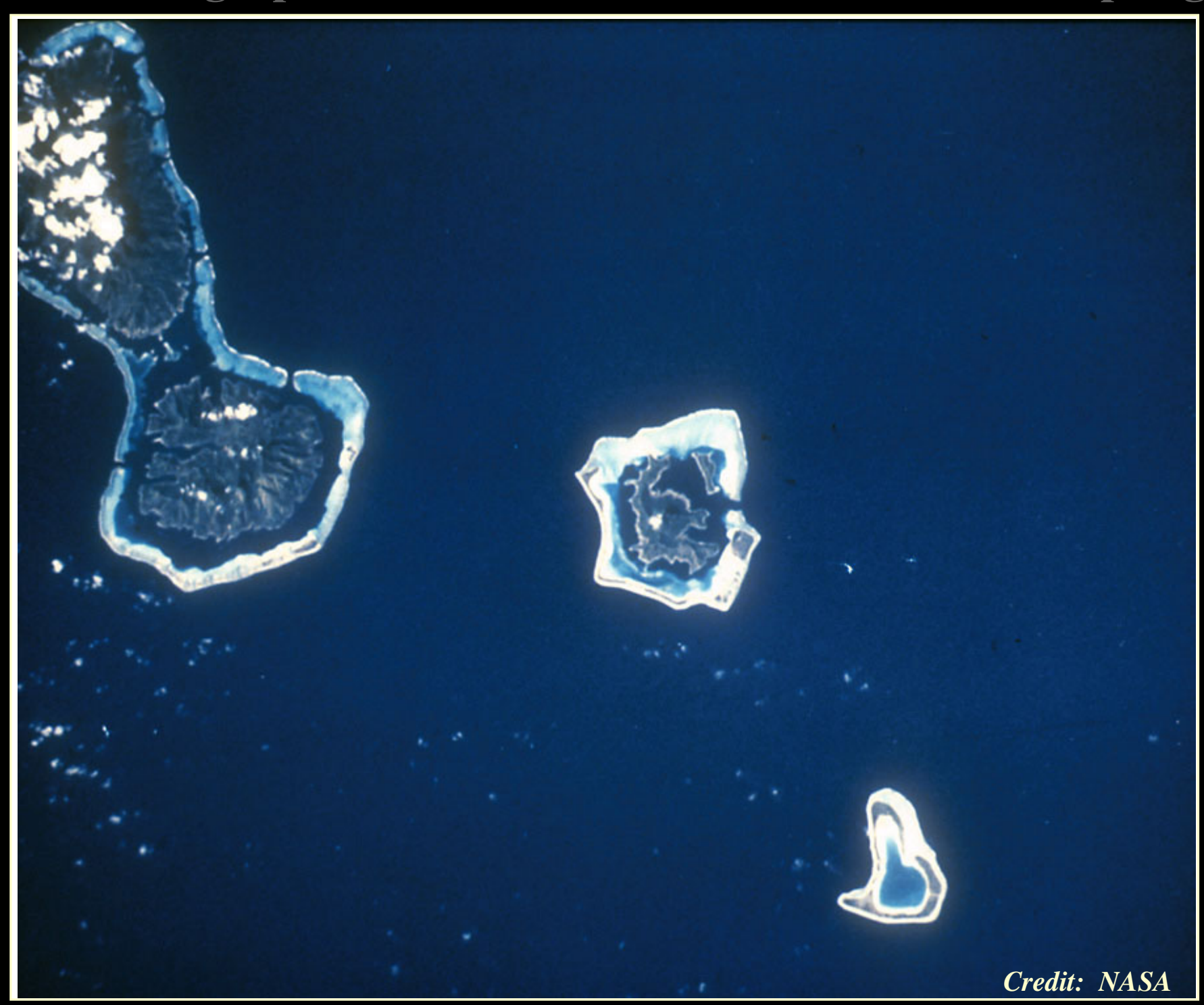


Iceland 2000: Faith in the Future

The Role of Religion and Science in the New Millennium

Space shuttle (STS-8) photograph of coral reefs around two volcanic islands, a barrier reef on Raiatea (center) and a fringing reef on Tahaa (right), and an atoll (around a submerged volcano) on Tapai (left), in the Bora-Bora archipelago, Tahiti. Coral reefs, which support a diverse assemblage of marine biota $(6,000$ to 8,000 species of fish and a still unknown number of species of plants, algae, and invertebrate animals), are distributed to lat $30^{\circ}$ north and south around the Equator where annual seawater temperatures range between $20^{\circ} \mathrm{C}$ and $30^{\circ} \mathrm{C}$. Coral reefs harbor 25 percent of Earth's marine species. Corals first appeared in the geologic record $450 \mathrm{Ma}$ (during the Ordovician Period) and are currently represented by 2,500 different species. Coral reefs are particularly vulnerable to environmental disruptions caused by direct (deforestation and dispersal of sediments) and indirect (warming of the ocean) activities of humans. Many coral reef experts believe that all of the world's coral reefs are threatened and at risk of loss. (See National Geographic Society's Coral world map and virtual reefscape poster, 2000, for more comprehensive information). Photograph 83-HC-602 courtesy of NASA. 
Iceland 2000: Faith in the Future

The Role of Religion and Science in the New Millennium

Landsat Thematic Mapper Image of Compound Crescentic Dunes in the United Arab Emirates

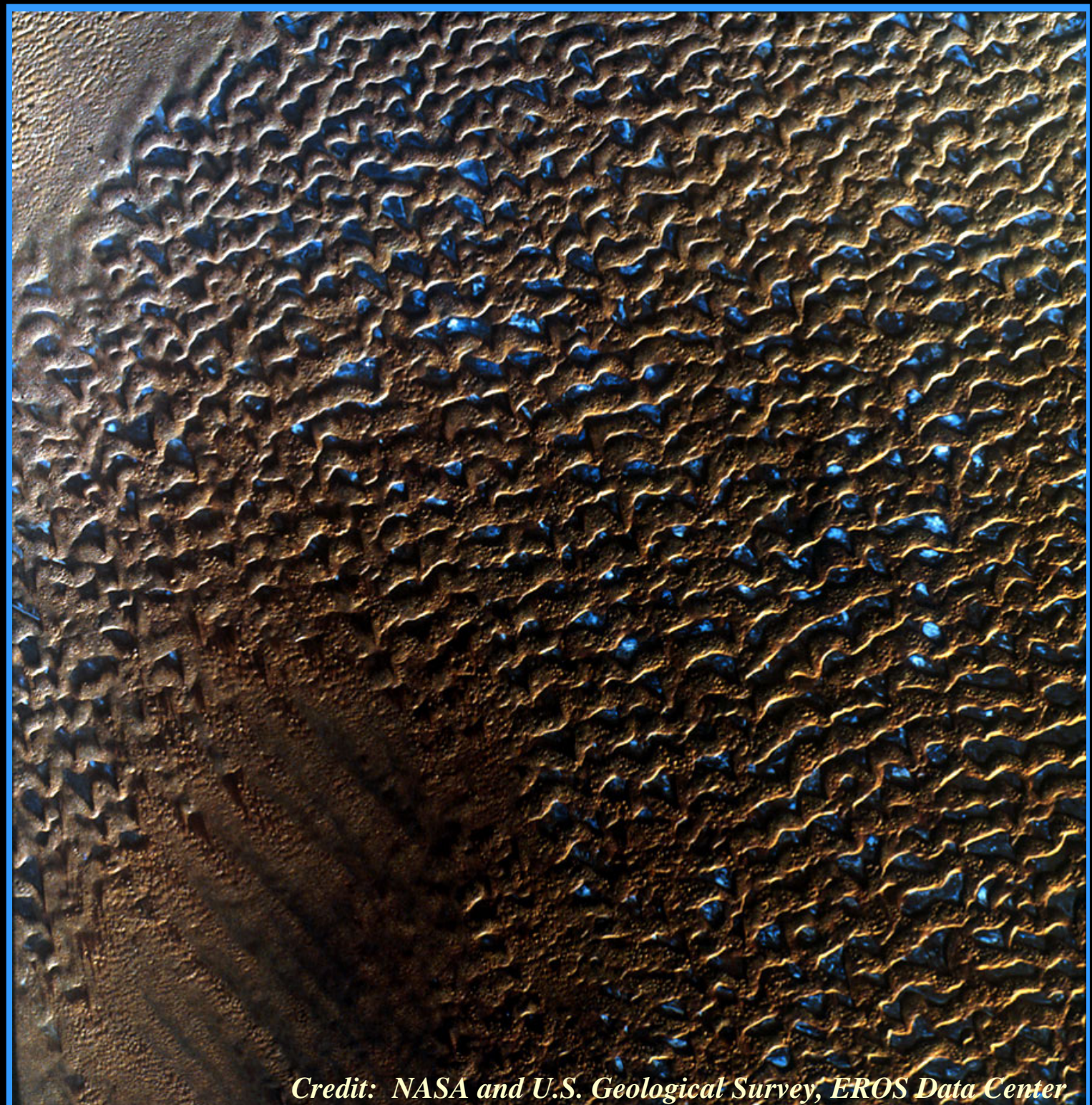


Iceland 2000: Faith in the Future

The Role of Religion and Science in the New Millennium

Landsat thematic mapper (TM) false-color composite image of compound crescentic dunes in the United Arab Emirates taken on 3 December 1988. Landsat image courtesy of the U.S. Geological Survey EROS Data Center. Dunes are an extremely mobile and dynamic part of the lithosphere, a diverse variety of land forms created by a large source of sediment (lithosphere), strong seasonal winds (atmosphere), and dry climate (climatic processes). 


\section{Iceland 2000: Faith in the Future}

The Role of Religion and Science in the New Millennium

\section{Number of Species in Major Taxonomic Groups Assigned a Binomial Name}

\section{$\underline{\text { Taxonomic group }}$}

Bacteria and archaeans

Protozoans and algae

Fungi and lichens

Plants

Insects and myriapods

Chelicerates (spiders, scorpions, horseshoe crabs)

Nematode worms

Flatworms

Annelid worms

Cnidarians (jellyfish, corals, anemones)

Sponges

Mollusks

Crustaceans

Fish

Reptiles and amphibians

Birds

Mammals

Other organisms (e.g., echinoderms)
Approximate number of species described

$$
\begin{array}{r}
4,000 \\
80,000 \\
100,000 \\
270,000 \\
963,000 \\
75,000 \\
25,000 \\
20,000 \\
12,000 \\
10,000 \\
10,000 \\
70,000 \\
40,000 \\
22,000 \\
10,500 \\
10,000 \\
4,500 \\
10,000
\end{array}
$$


Iceland 2000: Faith in the Future

The Role of Religion and Science in the New Millennium

Number of species in major taxonomic groups of the biosphere that have been assigned a binomial name (from Morell, V., 1999, The variety of life Wilderness headcount_-The sixth extinction-Restoring Madagascar. In search of solutions: National Geographic, v. 195, no. 2, p. 6-87. 
Iceland 2000: Faith in the Future

The Role of Religion and Science in the New Millennium

\section{Sunset Over West Falmouth Harbor, Cape Cod, Massachusetts}

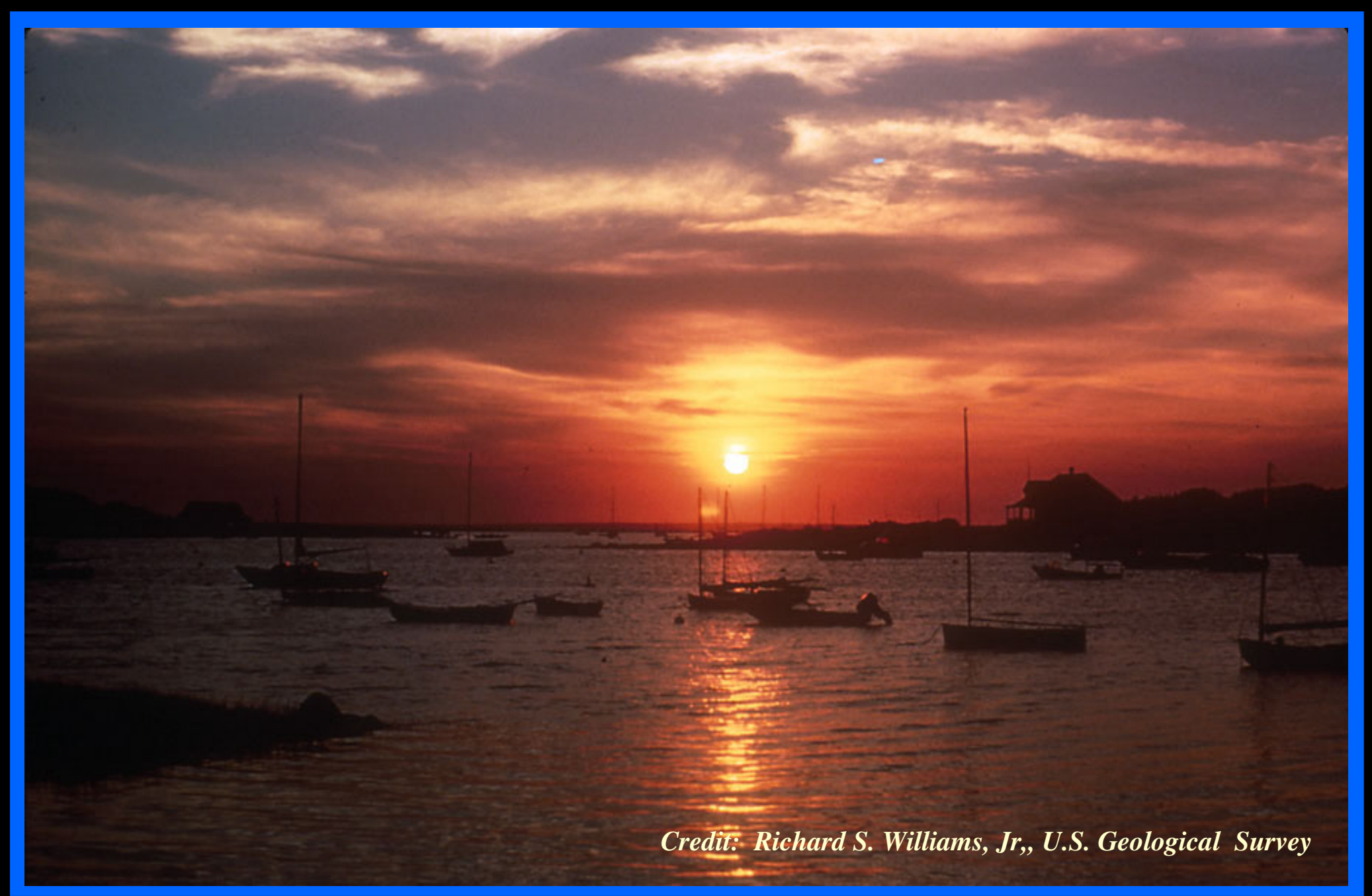




\section{Iceland 2000: Faith in the Future}

The Role of Religion and Science in the New Millennium

Sunset over West Falmouth Harbor, Cape Cod, Massachusetts [hydrosphere, atmosphere, and Sun (solar energy)]. Photograph by Richard S. Williams, Jr., U.S. Geological Survey. 
Iceland 2000: Faith in the Future

The Role of Religion and Science in the New Millennium

\section{Satellite Image of Sea Surface Temperature Off the East Coast}

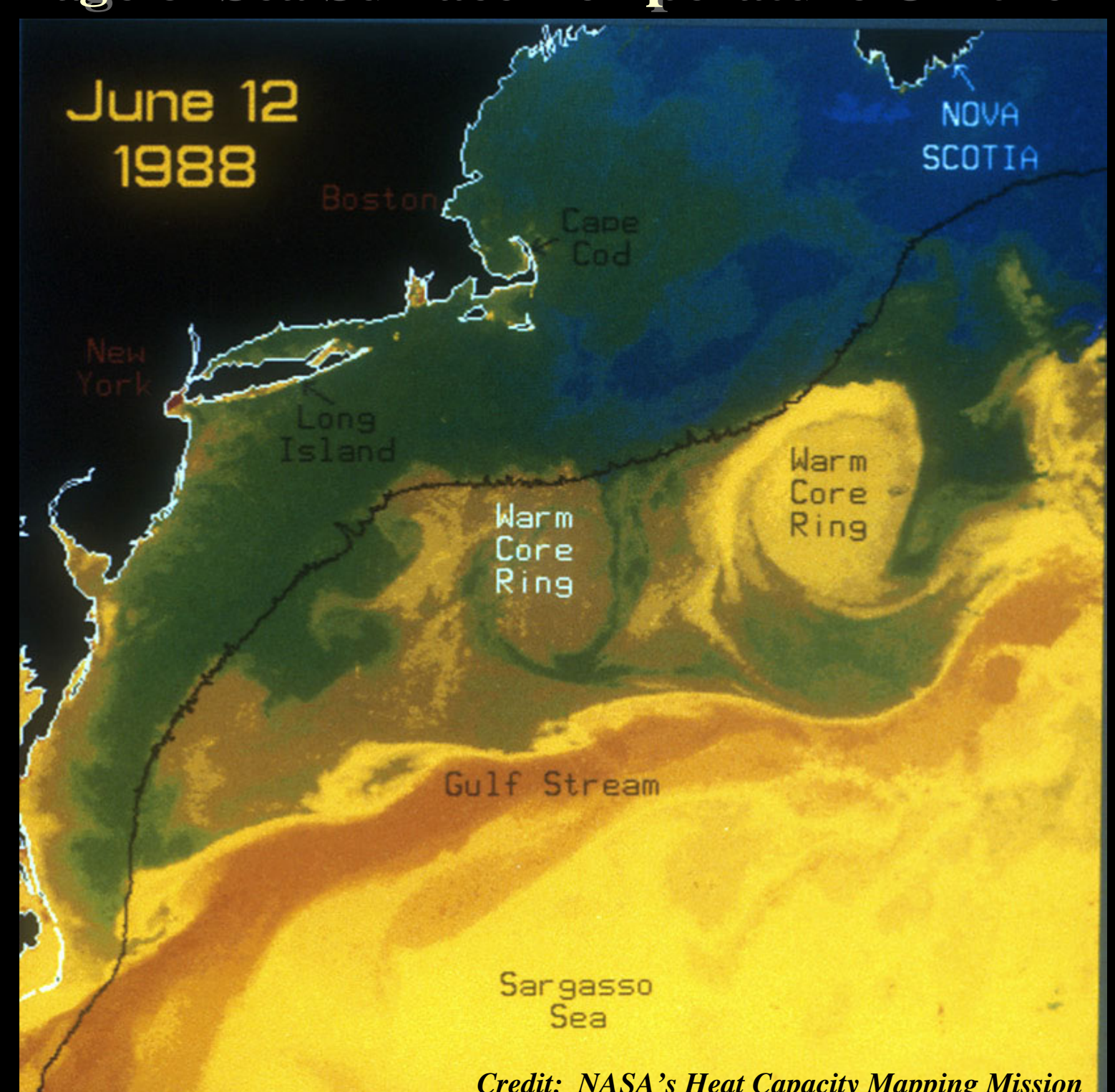




\section{Iceland 2000: Faith in the Future}

The Role of Religion and Science in the New Millennium

Satellite thermal image from NASA's Heat Capacity mapping Mission (HCMM) showing contrast between warmer Gulf Stream waters and detached warm-core rings and colder, near-shore Labrador Current along the east coast of the United States and Nova Scotia, eastern Canada (hydrosphere). 
Iceland 2000: Faith in the Future

The Role of Religion and Science in the New Millennium

Landsat Image of Marine Eddies Off the Southwest Coast of Iceland

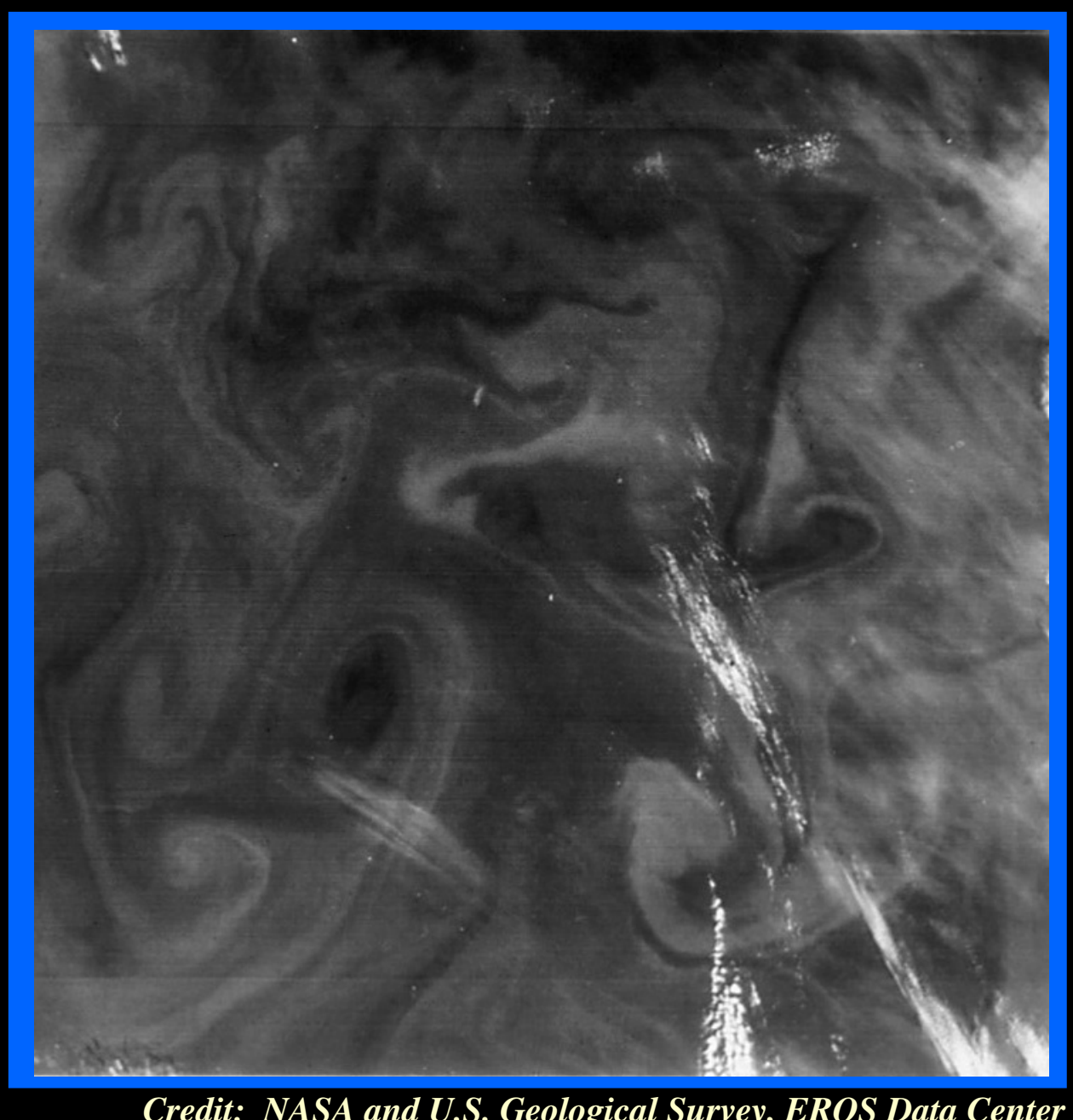

Credit: NASA and U.S. Geological Survey, EROS Data Center 
Iceland 2000: Faith in the Future

The Role of Religion and Science in the New Millennium

Landsat 1 multispectral scanner (MSS) image mosaic of current patterns, eddies, and multiple double gyres off the southwest coast of Iceland on 19 June 1976. The current patterns and double gyres (hydrosphere) are made visible by the strong plankton bloom in surface waters (biosphere). Landsat 1 images 251412019 and 2514-12021, band 4, courtesy of the U.S. Geological Survey's EROS Data Center. 
Iceland 2000: Faith in the Future

The Role of Religion and Science in the New Millennium

\section{Active Volcanoes of the World}

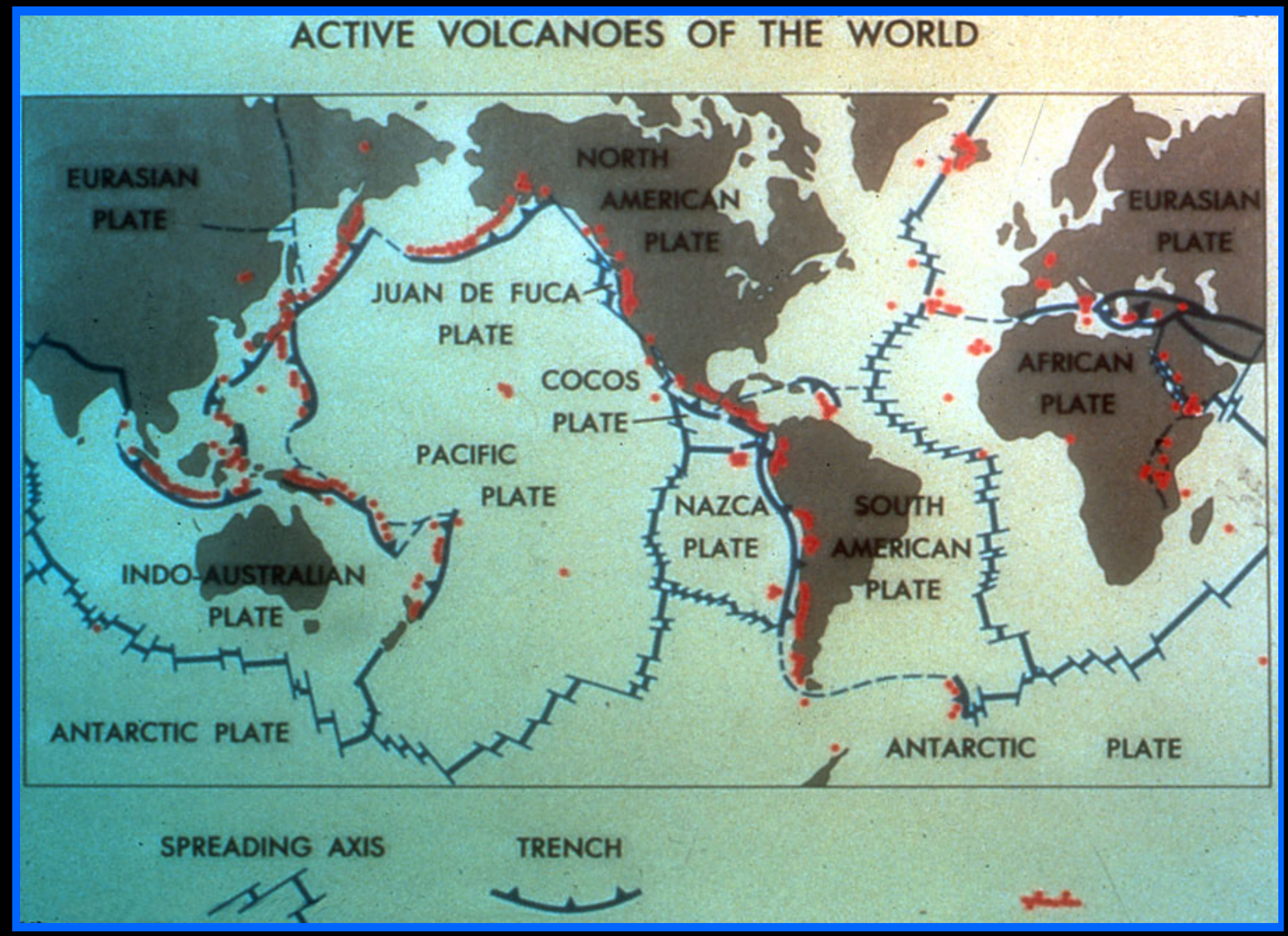




\section{Iceland 2000: Faith in the Future}

The Role of Religion and Science in the New Millennium

Sketch map showing spreading and convergent plate boundaries (blue) and the location of active volcanoes of the world (red) (lithosphere). Map courtesy of Robert I. Tilling, U.S. Geological Survey. 
Iceland 2000: Faith in the Future

The Role of Religion and Science in the New Millennium

Eruption of Mit. Hekla, Iceland in 1947

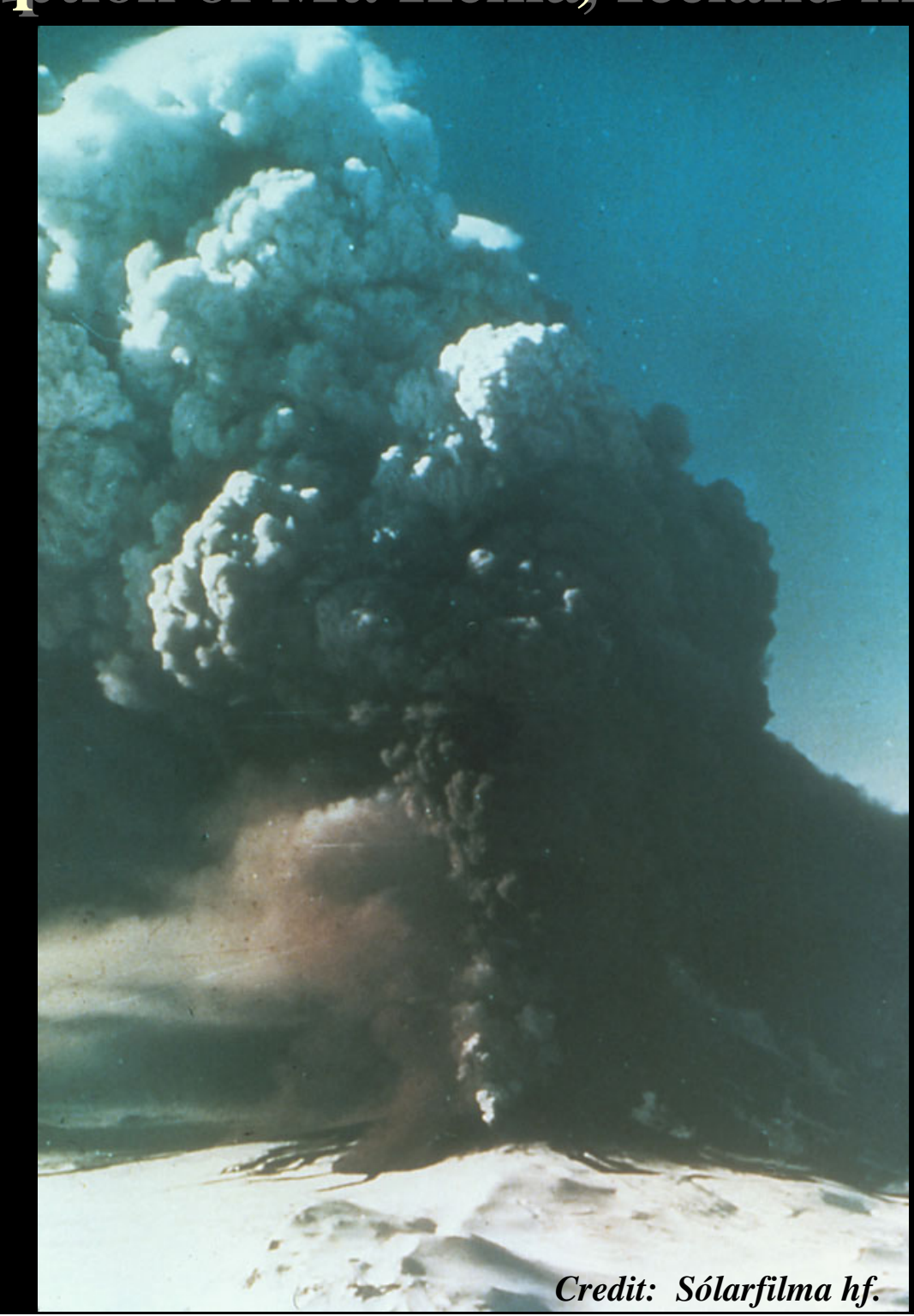


Oblique aerial photograph of explosive and effusive activity of Mt. Hekla Volcano, Iceland, in 1947 (lithosphere). The eruption cloud is $10 \mathrm{~km}$ (6.25 mi) high. Of the annual global volcanic activity on Earth, only 20 percent is subaerial (about 50 eruptions each year on the average). The other 80 percent is submarine (200 eruptions per year). Sólarfilm Slide No. $22 / 2^{\odot}$ from Sólarfilma hf., Reykjavík, Iceland. 
Iceland 2000: Faith in the Future

The Role of Religion and Science in the New Millennium

Landsat MSS False-Color Composite Image of Glacier Bay, Alaska

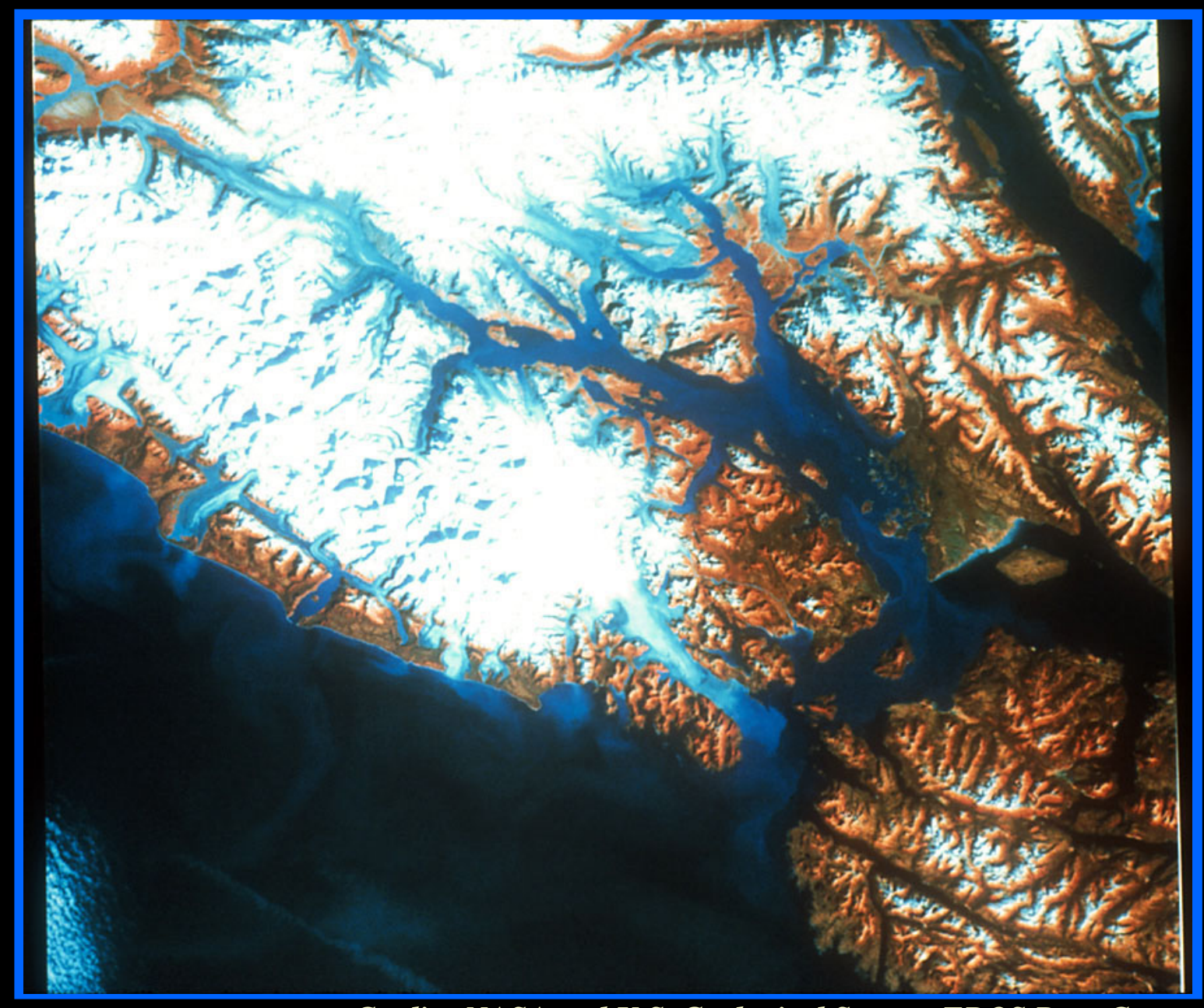


Iceland 2000: Faith in the Future

The Role of Religion and Science in the New Millennium

Landsat 1 MSS false-color infrared image of the glacierized Glacier Bay area, Alaska (cryosphere). Landsat 1 image 1416-19480, bands 4, 5, and 7; 12 September 1973, courtesy of the U.S. Geological Survey's EROS Data Center. 
Iceland 2000: Faith in the Future

The Role of Religion and Science in the New Millennium

\section{Human Impact on the Earth System}


Iceland 2000: Faith in the Future

The Role of Religion and Science in the New Millennium

\section{Growth of Human Population}

\begin{tabular}{|cc|}
\hline Year & Global population (estimated) (in billions) \\
\hline 8000 B.C. & 0.2 \\
\hline 1 & 0.3 \\
\hline 1000 A.D. & 0.5 \\
\hline 1500 & 0.5 \\
\hline 1830 & 1.0 \\
\hline 1930 & 2.0 \\
\hline 1960 & 3.0 \\
\hline 1975 & 4.0 \\
\hline 1987 & 5.0 \\
\hline 1999 & 6.0 \\
\hline 2060 & $10-11$ \\
\hline
\end{tabular}

Credit: United Nations Population Reference Bureau, 1994; courtesy of Piotr Kowalski, Montrouge, France 


\section{Iceland 2000: Faith in the Future}

The Role of Religion and Science in the New Millennium

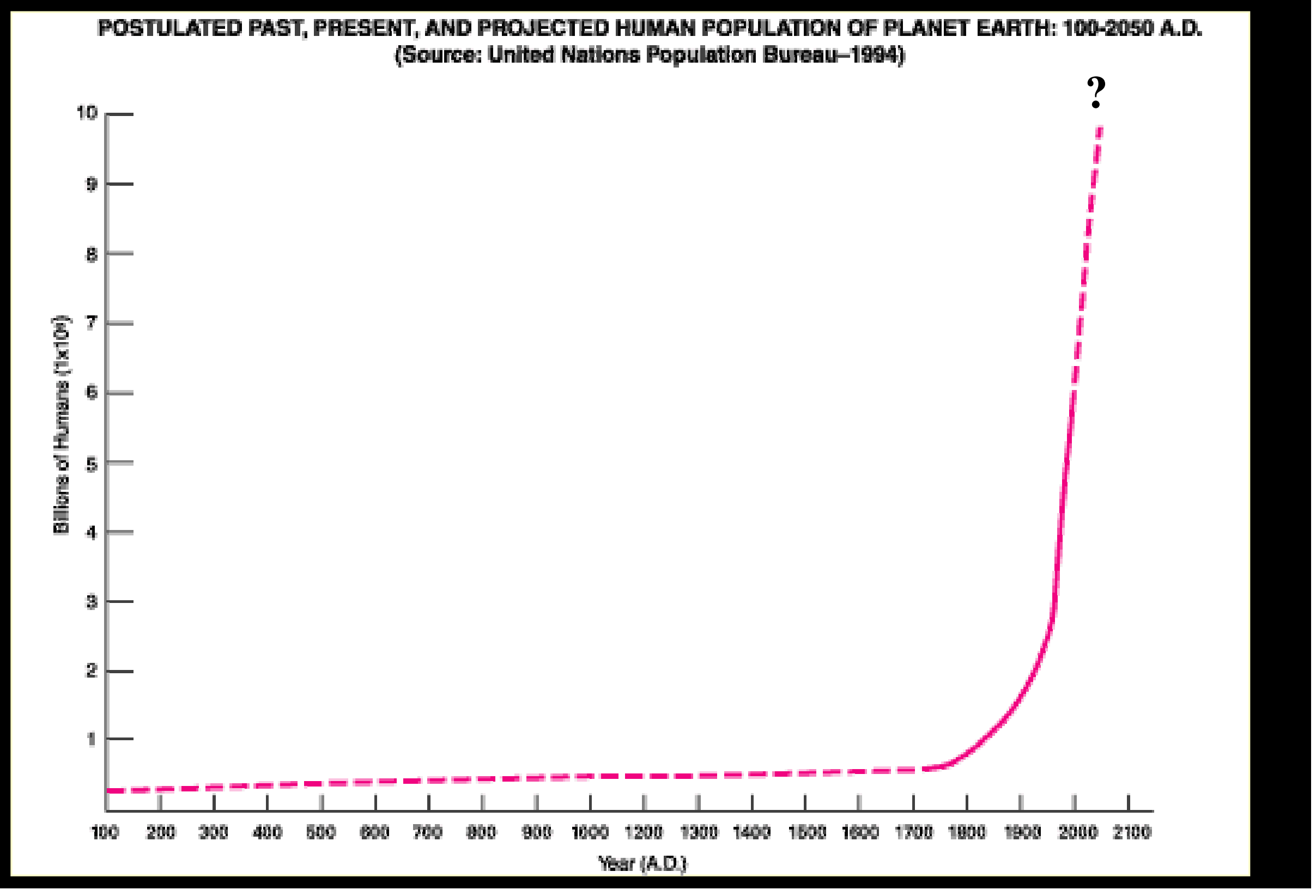


Iceland 2000: Faith in the Future

The Role of Religion and Science in the New Millennium

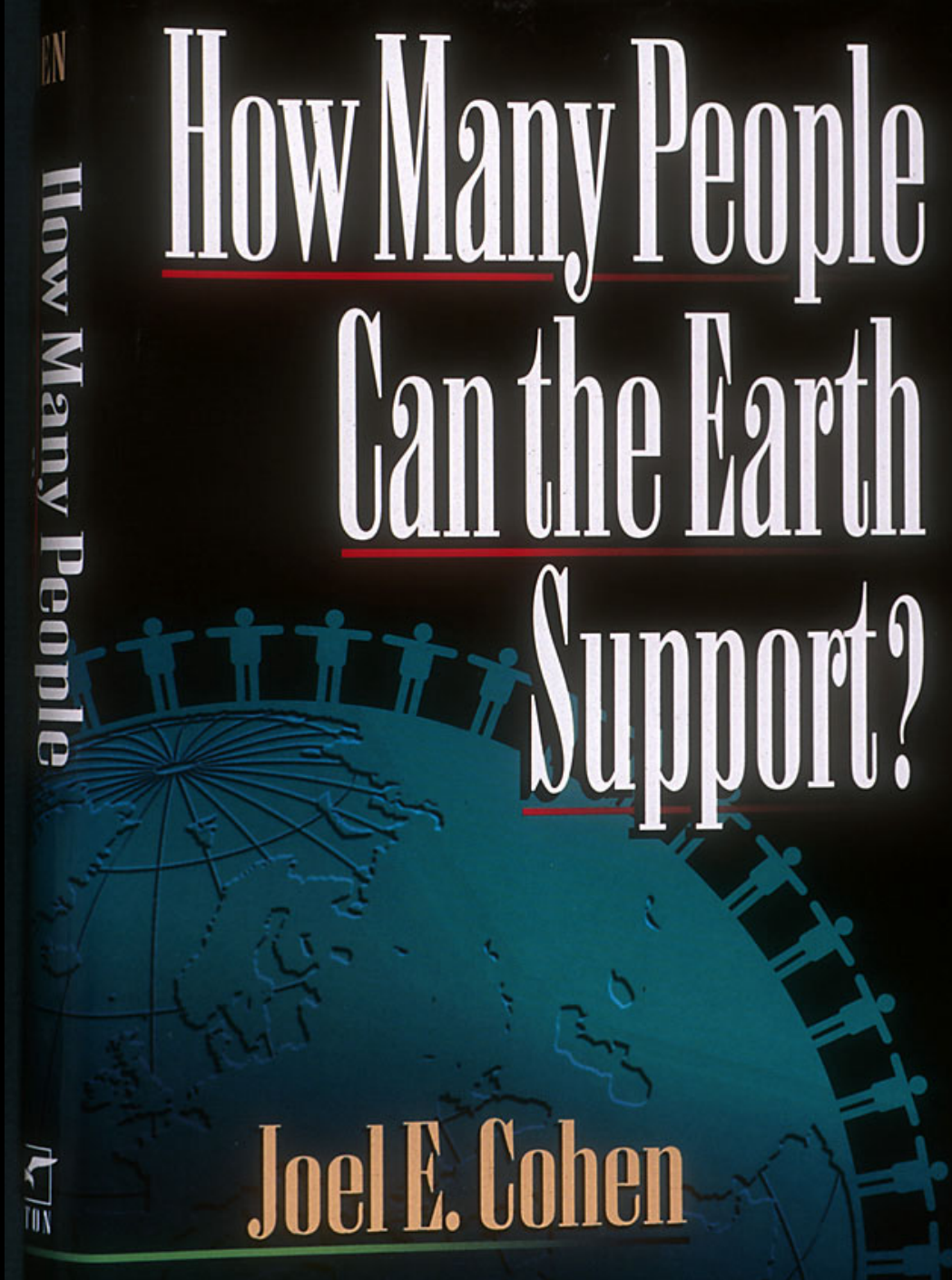


Iceland 2000: Faith in the Future

The Role of Religion and Science in the New Millennium

Cover of book by Joel E. Cohen: How many people can the Earth support?, 1995, New York, W.W. Norton and Co., 523 p. (biosphere). 
Iceland 2000: Faith in the Future

The Role of Religion and Science in the New Millennium

Human Population of the Top 10 Nations (in millions)

\begin{tabular}{|l|c|}
\hline China & 1,210 \\
\hline India & 968 \\
\hline United States & 268 \\
\hline Indonesia & 210 \\
\hline Brazil & 165 \\
\hline Russia & 148 \\
\hline Pakistan & 132 \\
\hline Japan & 126 \\
\hline Bangladesh & 125 \\
\hline Nigeria & 107 \\
\hline
\end{tabular}


Iceland 2000: Faith in the Future

The Role of Religion and Science in the New Millennium

\section{NATION \& WORLD}

\section{India population:

Experts see doubling in 100 years THE ASSOCIATED PRESS WASHINGTON - It has taken thousands of years for the popula. tion of India to swell to 1 billion. It
may take just 100 years for India to may take just 100 years for India to
add another billion. How successful the Indian govern cexual education among females in the next several decades will be critical in determining just how quickly the population there increases, the author of a new report on world population says.

Currently, India is home to one sixth of the world's 6 billion people.
By mid-century, India's population now has 13 percent of the world's could reach 1.6.billion people, help. population, it has 69 percent of the ing to swell the world population to 9 world's HIV or AIDS cases.

billion, according to the report by Europe's population is expected to scheduled for release today. Bureau decrease from 728 million now to By 2050, India could surpass Chi- said. It is a decline that the report By 2050 , country with the world's agencies for the European Union largest population, said Carl Haub, and United Nations have also pre one of the report's authors. The bu- dicted because of declining birth reau is a Washington-based private, rates.

The U.S. population is expected to At that rate, what we're talking rise from 275 million now to 403 milabout is the very real possibility of lion by mid-century, moderate adia adding 1 billion people in this growth due to an overall positive entury. That's unheard of, Haub economic forecast and continue "But yesterday. Bentrends in Africa and Europe will dia is the country to watch go, In be important in determining how he said

ast the world's population grows. India surpassed the 1 billion mark The population of the African con- in population in May, and $114 \mathrm{mil}$ tinent is expected to rise from 800 lion of them are under age 4 - a million now to 1.8 billion in 2050, group that if counted on its own even with a high percentage of AIDS would amount to the 11th largest and HIV-related cases. While Africa country in the world.
The present, the future

The world's population is estimat- $\quad$ 9) Japan, 127 million $\begin{array}{ll}\text { ed at just more than } 6 \text { billion to- } & 10) \text { Nigeria, } 123 \text { million }\end{array}$ estimates the world's population could reach 9 billion by mid-cent ry. Here is a list of the world's largest countries now, and what they are projected to be by 2050 .

World's largest

countries by population

in 2000:

1) China, 1.2 billion ,

2) India, 1 billion

3) United States, 275 million

4) Indonesia, 212 million

5) Brazil, 170 million

6) Pakistan, 151 million

7) Russia, 145 million

8) Bangladesh, 128 million a World's largest countries by population

1) India, 1.6 billion

2) China, 1.3 billion

3) United States, 403 million

4) Indonesia, 312 million

5) Nigeria, 304 million

6) Pakistan, 285 million

7) Brazil, 244 million

8) Bangladesh, 211 million

9) Ethiopia, 188 million

10) Democratic Rep. of Congo (Zaire), 182 million

Source: Population Reference Burea 


\section{Population Momentum}

The world population is still rising, although birth rates have declined recently in many countries. China and Mexico are among the countries that have been particularly successful in controlling their population growth.

Most of the population growth this century has been in less developed countries:

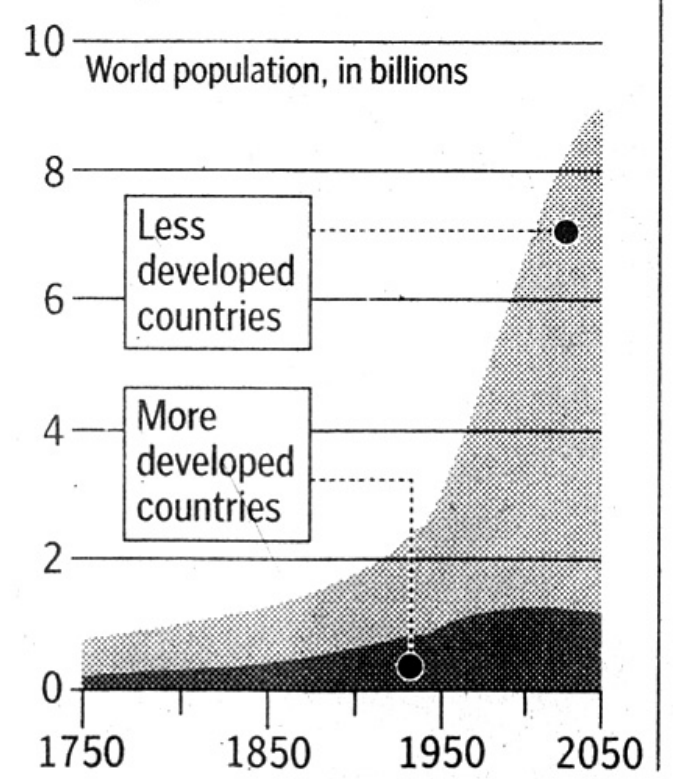

More than half of world population growth will occur in Asia, including $25 \%$ in India and China. Population in developed countries has been stable for several years.

Africa

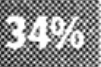

Other Asia (1):

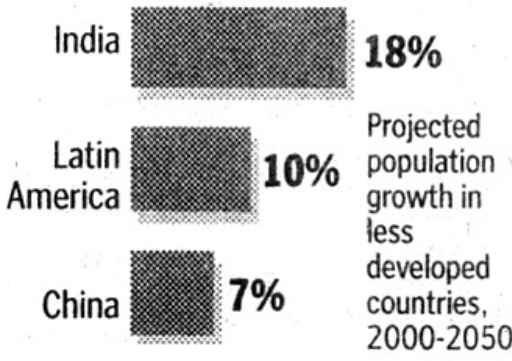

SOURCES: U.N. Population Division, Population Reference Bureau 
REFLECTIONS ON SUSTAINABILITY, POPULATION GROWTH, AND THE ENVIRONMENT—REVISITED - Bartlett (1999)

"Every day the planet sees a net increase...of about [250,000]...people."

"carrying capacity"... "refers to the limit to the number of humans the Earth can support in the long term without damage to the environment" (Giampietro et al., 1992)

"...the scale and scope of human activities have, for the first time, grown to rival the natural processes that built the biosphere and that maintain it as a place where live can flourish."... "It is estimated that somewhere between 20 and 40 percent of the earth's primary productivity, from plant photosynthesis on land and in the sea, is now appropriated for human use."

"Can you think of any problem, on any scale, from microscopic to global, whose long-term solution is in any demonstrable way, aided, assisted, or advanced, by having larger populations at the local level, the state level, the national level, or globally?" 


\section{Iceland 2000: Faith in the Future}

The Role of Religion and Science in the New Millennium

Reflections on sustainability, population growth, and the environment (1999) by Al Bartlett, Professor of Physics, University of Colorado, Boulder, Colorado; selected excerpts from his paper (human impact on the geosphere and biosphere). 


\section{Civilization - The Magazine of the Library of Congress- Aug/Sep 99 (p. 67):}

Voice of Authority

Edward 0. Wilson

Two-time Pulitzer Prize winner and Harvard entomologist

"In the $21^{\text {st }}$ century, we are going to pass through a bottleneck. The land required to maintain one American's standard of living, on average, is 12 acres; the amount required to sustain the current standard of living of someone in one of the developing countries, where 80 percent of the world's population lives, is one acre. Now here's the problem: The whole world wants to live like Americans. Thus we have the aftershock following the population explosion: not only too many people, but people attempting legitimately, understandably, to increase the quality of their lives. It's been estimated that to bring the whole world up to America's standard of living would require two more planet Earths. The results, politically, economically, and environmentally, of the rush to achieve that impossibility in the next century will be our greatest problem." 
Statement by Edward O. Wilson, two-time Pulitzer Prize awardee and Harvard entomologist about human impact on the geosphere and biosphere of the Earth. Statement published in Civilization (The Magazine of the Library of Congress) in Aug/Sep 1999 (p. 67). Prof. Wilson says that we will need three Planet Earths in the latter part of the $21^{\text {st }}$ century, if the total human population is to achieve the same standard of living as the United States. 
Iceland 2000: Faith in the Future

The Role of Religion and Science in the New Millennium

Roadway Jammed with Cars

(5) 
Iceland 2000: Faith in the Future

The Role of Religion and Science in the New Millennium

Oblique photograph of major highway filled with cars and trucks at a toll interchange. Consider the demand for fossil energy to fuel cars, trucks, electricity generation, etc., of a rapidly expanding human population (human impact on the geosphere and biosphere) from a finite source. Photograph furnished by Dr. Dorothy K. Hall, NASA Goddard Space Flight Center; source unknown. 
Iceland 2000: Faith in the Future

The Role of Religion and Science in the New Millennium

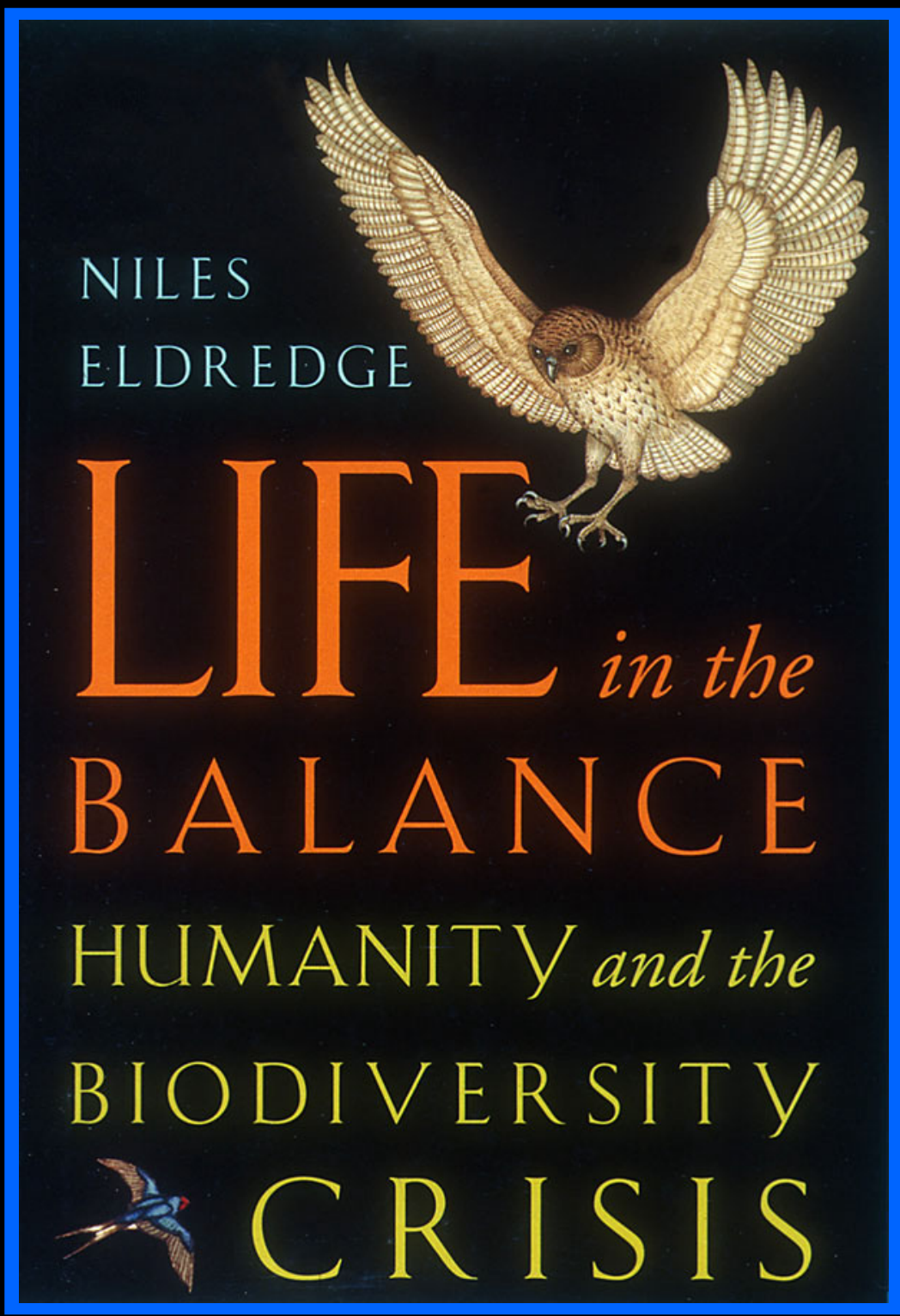


Iceland 2000: Faith in the Future

The Role of Religion and Science in the New Millennium

Cover of book by Niles Eldredge, Life in the balance. Humanity and the biodiversity crisis, 1998, Princeton, New Jersey, Princeton University Press, 224 p. (human impact on the biosphere). 
Iceland 2000: Faith in the Future

The Role of Religion and Science in the New Millennium
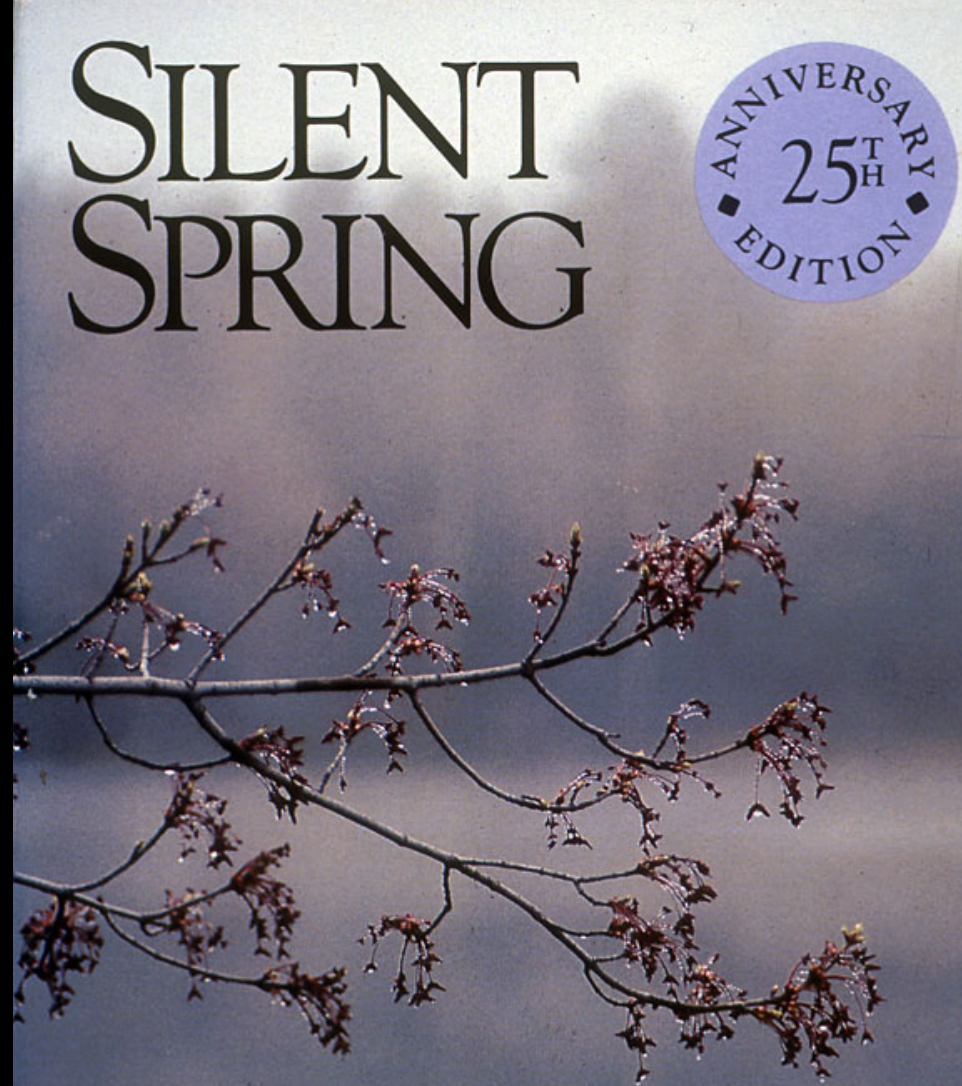

\section{RACHEL CARSON}




\section{Iceland 2000: Faith in the Future}

The Role of Religion and Science in the New Millennium

Cover of book by Rachael Carson, Silent Spring, 1962: Boston, Houghton Mifflin Co., 368 p. (25 th anniversary edition, 1987) (human impact on the biosphere). 
Iceland 2000: Faith in the Future

The Role of Religion and Science in the New Millennium

\section{Global Status of Bird Species}

\begin{tabular}{|l|c|}
\hline \multicolumn{1}{|c|}{ Status } & Species Number \\
\hline Stable or Increasing & 3,500 \\
\hline In Decline & 5,000 \\
\hline $\begin{array}{l}\text { Nearly Threatened } \\
\text { with Extinction }\end{array}$ & 600 \\
\hline $\begin{array}{l}\text { Threatened with } \\
\text { Extinction }\end{array}$ & 1,000 \\
\hline
\end{tabular}

Credit: Youth, H., 1994, Birds are in decline; Vital Signs 1994, Washington, D.C., Worldwatch Institute, p.128-129. 


\section{Iceland 2000: Faith in the Future}

The Role of Religion and Science in the New Millennium

Table showing global status of bird species. From Youth, H., 1994, Birds are in decline, in Brown, L.R., Kane, H., Roodman, D.M., eds., Vital signs 1994: Washington, DC, Worldwatch Institute, p. 128-129 (human impact on the biosphere). 
Iceland 2000: Faith in the Future

The Role of Religion and Science in the New Millennium

\section{Twin Landsat Images Showing Changes in Amazon Rainforest}

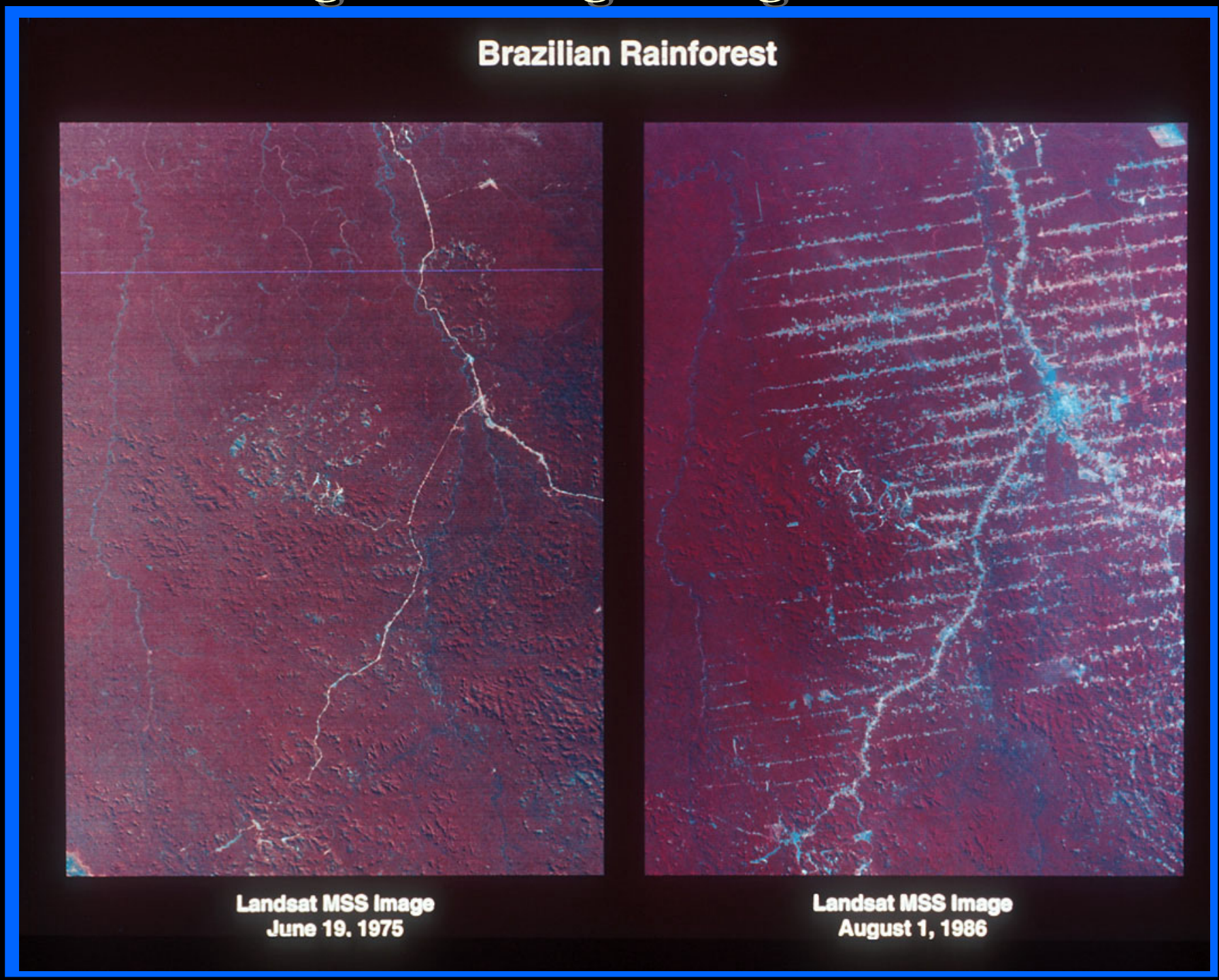


Iceland 2000: Faith in the Future

The Role of Religion and Science in the New Millennium

Changes in the Brazilian rainforest on two Landsat MSS false-color infrared images, one acquired on 19 June 1975, the other acquired 11 years later on 1 August 1986. The construction of a major road through the rainforest in the Territory of Rondônia has markedly improved access by settlers, who have built numerous parallel roads orthogonal to the main road (human impact on the biosphere). 


\section{"The Historical Roots of Our Ecological Crisis" (tugn white, Jri, science 1967)}

"Especially in its Western form, Christianity is the most anthropocentric religion the world has ever seen."

"I personally doubt that disastrous ecological backlash can be avoided simply by applying to our problems more science and more technology. Our science and technology have grown out of Christian attitudes toward man's relationship to nature which are almost universally held not only by Christians and neo-Christians but also by those who fondly regard themselves as post-Christians. Despite Copernicus, all the cosmos rotates around our little globe. Despite Darwin, we are not, in our hearts, part of the natural process. We are superior to nature, contemptuous of it, willing to use it for our slightest whim."

"Both our present science and our present technology are so tinctured with orthodox Christian arrogance toward nature that no solution for our ecologic crisis can be expected from them alone. Since the roots of our trouble are so largely religious, the remedy must also be essentially religious, whether we call it that or not. We must rethink and refeel our nature and destiny. The profoundly religious, but heretical, sense of primitive Franciscans for the spiritual autonomy of all parts of nature may point a direction. I propose Francis as a patron saint for ecologists." 
Iceland 2000: Faith in the Future

The Role of Religion and Science in the New Millennium

Excerpts from Lynn White, Jr.'s 1967 Science article, The historical roots of our ecological crisis. He says that "Since the roots of our trouble are largely religious, the remedy must also be essentially religious,..." (human impact on the geosphere and biosphere). 
Iceland 2000: Faith in the Future

The Role of Religion and Science in the New Millennium

\section{Scientific and Ethical Challenges to Science and Religion}

- Will natural scientists strive to educate humanity about the accelerating human impact on the entire Earth System as they labor to better understand and expand our knowledge of the natural and human history of the Earth?

- Will humans use our new knowledge of the Earth's natural and human history to stop further degradation of the planet's ecosystems and extinction of its biota?

- Will the world's religions make stewardship of the planet (the Earth's biosphere and geosphere) a primary moral imperative?

- Will science provide the facts based on observation and will religion provide the moral and ethical force based on faith to guide individuals in making the personal decisions (e.g., size of family, consumption of resources, impact on the environment) that will collectively improve stewardship of the Earth and avoid the "Tragedy of the Commons?"

- Will all humans of all cultures and religions reaffirm the global importance of planetwide conservation of the Earth's biotic heritage - one that is based on a Do No Harm ethic? 
Iceland 2000: Faith in the Future

The Role of Religion and Science in the New Millennium

\section{Stewardship: Common Ground for Science and Religion}

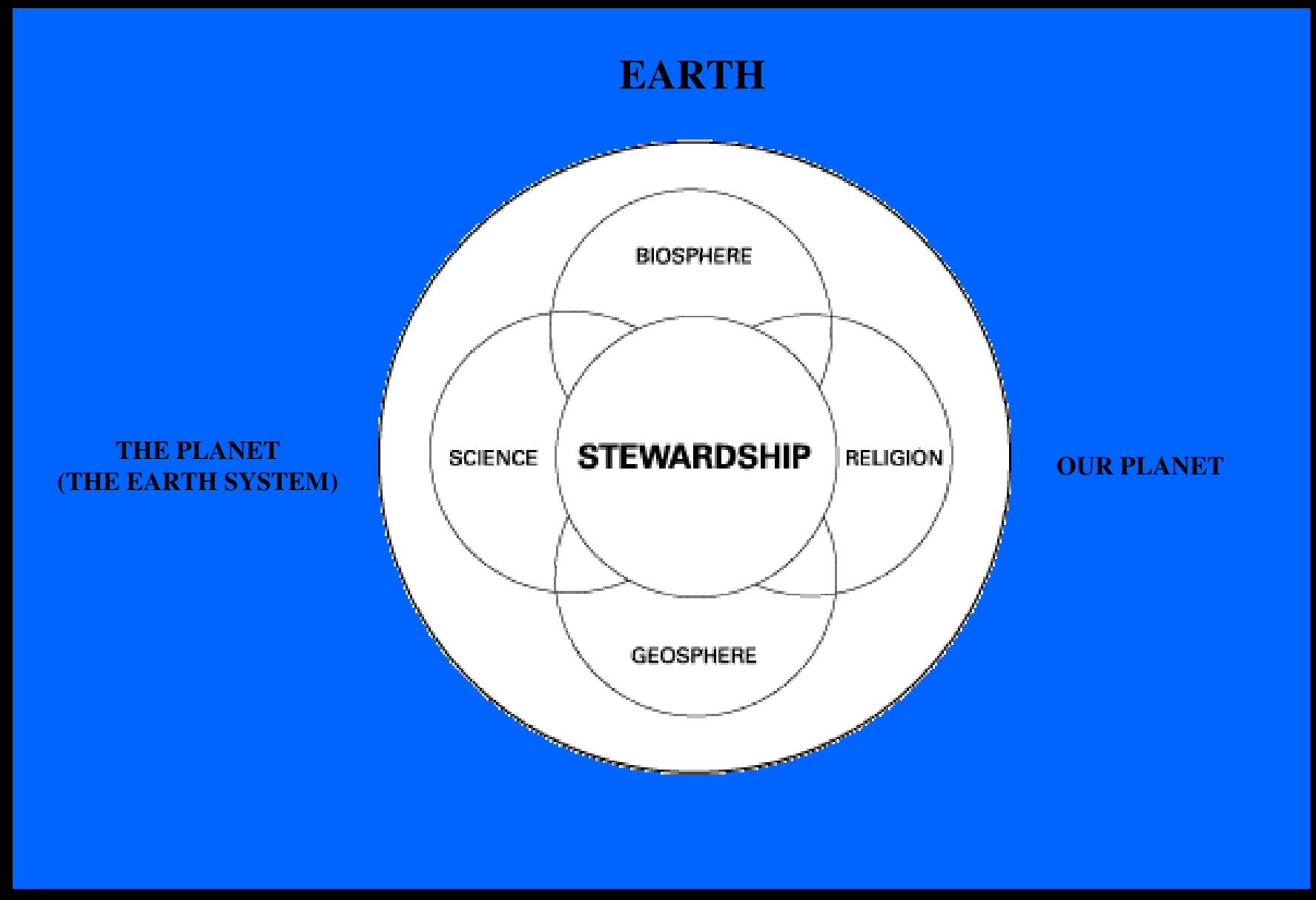




\section{Epilogue}

Mourn not the dead who in the cool earth lie Dust to dust

The calm sweet earth that mothers all who die As all men must

But rather mourn the apathetic throng

The cowed and the meek

Who see the world's great anguish and its wrong And dare not speak 
Iceland 2000: Faith in the Future

The Role of Religion and Science in the New Millennium

\section{Apollo 17 Photograph of the Earth}

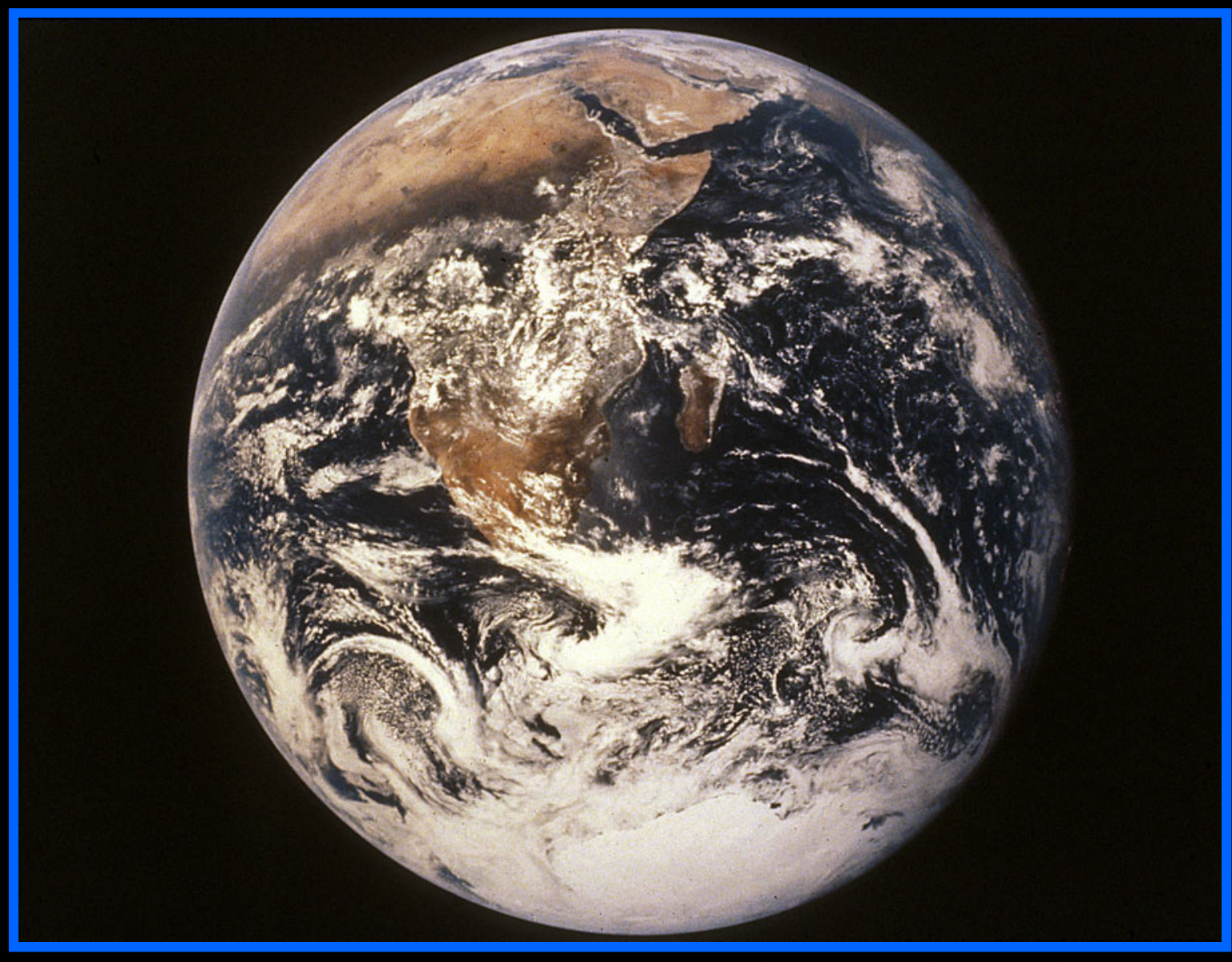


Iceland 2000: Faith in the Future

The Role of Religion and Science in the New Millennium

Apollo 17 photograph of the Earth taken in 1972 by the astronaut/geologist, Harrison H. Schmidt. When Buckminster Fuller, the noted American architect and inventor of the geodesic dome, first saw this photograph, he referred to the planet as "Spaceship Earth." His was an apt analogy, because a spaceship is selfcontained, with finite resources to be used by its passengers. The 6 billion plus humans on Planet Earth are also "passengers", but the planet must be shared with at least 30 million other species. The actions humans take, individually and collectively during the $21^{\text {st }}$ century, will definitely determine the fate of many millions of species, including our own. Will all humans of all cultures and religions reaffirm the global importance of planet-wide conservation of the Earth's biotic heritage? Will science provide the facts based on observation? Will religion provide the moral and ethical force to guide individuals in making personal decisions? Will we all collectively improve Stewardship of the Earth? Will the world's religions make Stewardship of the planet (the Earth's biosphere and geosphere, especially the former) a primary Moral Imperative? 
Postscript

At the $4^{\text {th }}$ Symposium on Religion, Science and the Environment, a declaration for the environment was signed in Venice, Italy, in 2002, by many notable scientists and religious leaders, including the leader of the Roman Catholic Church, Pope John Paul II of the Vatican, and the leader of the Greek Orthodox Church, Ecumenical Patriarch Bartholomew I of Constantinople. The symposium focused on the issue of environmental ethics and explored common ground for an ethical code. In July 2002, Archbishop John Bathersby, speaking on behalf of the Roman Catholic Church of Australia, said that Australian Roman Catholics must be mobilized "to take decisive action to protect the natural world before it is too late." 